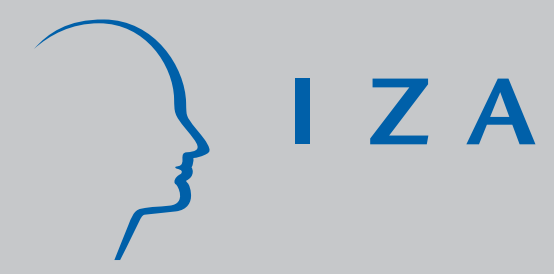

IZADP No. 1701

The Impact on Nutrition of the Intrahousehold Distribution of Power

Habiba Dj ebbari

August 2005 


\title{
The Impact on Nutrition of the Intrahousehold Distribution of Power
}

\author{
Habiba Djebbari \\ Université Laval, CIRPÉE \\ and IZA Bonn
}

\section{Discussion Paper No. 1701 August 2005}

\author{
IZA \\ P.O. Box 7240 \\ 53072 Bonn \\ Germany \\ Phone: +49-228-3894-0 \\ Fax: +49-228-3894-180 \\ Email: iza@iza.org
}

\begin{abstract}
Any opinions expressed here are those of the author(s) and not those of the institute. Research disseminated by IZA may include views on policy, but the institute itself takes no institutional policy positions.
\end{abstract}

The Institute for the Study of Labor (IZA) in Bonn is a local and virtual international research center and a place of communication between science, politics and business. IZA is an independent nonprofit company supported by Deutsche Post World Net. The center is associated with the University of Bonn and offers a stimulating research environment through its research networks, research support, and visitors and doctoral programs. IZA engages in (i) original and internationally competitive research in all fields of labor economics, (ii) development of policy concepts, and (iii) dissemination of research results and concepts to the interested public.

IZA Discussion Papers often represent preliminary work and are circulated to encourage discussion. Citation of such a paper should account for its provisional character. A revised version may be available directly from the author. 


\section{ABSTRACT \\ The Impact on Nutrition of the Intrahousehold Distribution of Power*}

The distribution of income within the household is found to matter for the allocation of resources towards nutrition. Rural Mexican households do not pool income, nor do they attain a Pareto-efficient allocation of resources. In contrast to what is commonly done in the literature, I do not assume that only the head of household and his wife share the decisionmaking. In particular, I present a new test of the unitary model in the context of extended families, which acknowledges that any household member may participate to the decisionmaking as long as he or she earns some income. I find that a change in the number of income earners is associated with a change in food calorie consumption controlling for the change in household size and household income. Both the number and identities of income earners matter in the extended family. In particular, when a female household member starts earning income, food consumption increases substantively. When it is a male household member who starts earning income, it decreases substantively.

JEL Classification: I12, D13, I38

Keywords: nutrition, intrahousehold allocation, extended families

Corresponding author:

Habiba Djebbari

Université Laval

Department of Economics

Pavillon DeSève

Québec (QC) Canada G1K 7P4

Email: hdjebbari@ecn.ulaval.ca

\footnotetext{
* Suggestions from Ramon Lopez, Jeffrey Smith, Paul Schultz, Alice Mesnard, Pierre Dubois and Emmanuel Skoufias have been very helpful. I also thank participants to the 6th IZA European Summer School in Labor Economics, participants at NEUDC in Yale University, and seminar participants at the University of Toulouse, Georgetown University and Laval University for their comments.
} 


\section{Introduction}

This paper seeks to provide empirical evidence on the impact of the intrahousehold distribution of income on nutrition outcomes in rural Mexico. In 1998, women from the poorest households in rural regions of Mexico started to receive conditional cash transfers from the program for education, health and nutrition named PROGRESA. The literature on household decision-making is divided as to the effectiveness of targeting social transfers to a specific household member. On the one hand, according to the unitary household model, it should not matter who in the household receives the transfer, since optimal choices for the allocation of resources are made subject to a pooled budget constraint. There is already extensive evidence against the unitary model, although it is recognized that this evidence may suffer from issues of endogeneity, measurement error and the lack of support in the data for the joint distribution of incomes. ${ }^{1}$ On the other hand, the collective model of the household (Chiappori 1988, Browning and Chiappori 1998) acknowledges that household members have different preferences. The allocation of resources depends on the bargaining power of each family member. The main assumption of this model is that the allocation of resources is Pareto-efficient. ${ }^{2}$

The motivation for focusing in this paper on the allocation of resources between food groups is two-fold. First, food expenditures still represent 75 percent of the household budget for the poor rural households under study, suggesting that nutrition plays a major part in household

\footnotetext{
${ }^{1}$ See for example e.g. Thomas (1990) and Schultz (1990) in the context of developing countries, as well as Bourguignon, Browning, Chiappori and Lechène (1993), Fortin and Lacroix (1997) and Phipps and Burton (1998) for developed countries. See also Lundberg, Pollak and Wales (1997), Attanasio and Lechène (2002) and Duflo (2003) for studies that exploit an exogenous change in the intrahousehold distribution of income to identify the effect of the distribution of income.

${ }^{2}$ Much of the evidence on whether households attain Pareto-efficient outcomes is drawn from developed countries (e.g. France, Canada), where indeed households are found to make Pareto-efficient consumption decisions. For a recent survey of this literature, see Vermeulen (2002).
} 
decisions. ${ }^{3}$ Although most studies consider a system of demand equations for all goods consumed, consumption of goods other than food is often censored at zero. The second point is that resources might be efficiently allocated towards the aggregate outcomes for nutrition, clothing and education, but inefficiently allocated within each of these categories. ${ }^{4}$

A distinctive feature of the PROGRESA evaluation sample used in this study is that program benefits are postponed until the end of the evaluation period for a group of eligible households. This group acts as a control group. The sample consists of randomly selected treatment and control villages. Before random assignment, the control group is found to be similar to the treated group on all aspects (Behrman and Todd 1999). ${ }^{5}$ The purpose of the random assignment is to evaluate the mean impacts of the program on a range of outcomes using standard evaluation methods (e.g. difference-in-difference). ${ }^{6}$ In particular, this design allows measuring the overall impact of the program on nutrition (Hoddinott and Skoufias 2004).

In contrast, the identification of the effect of the distribution of income in the household on nutrition outcomes ideally requires that the data verify two conditions. First, transfers should be randomly targeted according to the gender of the decision-maker. Unfortunately, the design of the evaluation does not include this type of randomization, as all cash payments are targeted to women. Yet, as in Attanasio and Lechène (2002), I exploit the experimental nature of the data to identify the effect of a rise in women's income on nutrition patterns. This allows testing the unitary model restrictions, under the hypothesis that the husband and the wife are the sole

\footnotetext{
${ }^{3}$ In rural areas, food purchased on a market does not represent food consumption since consumption out of own production is still common. For example, as many as half of the household in the sample report consuming but not purchasing tortillas, a staple food, in the previous seven days. In the paper, I rely on different food calorie aggregates to measure food consumption.

${ }_{5}^{4}$ Household members may only agree on an efficient allocation of resources towards the major spending items.

${ }^{5}$ Behrman and Todd (1999) do find significant differences in the baseline at the individual and household levels. This finding does not indicate a failure in the randomization process, since randomization is done at the locality level rather than the household level in order to minimize disruption.
} 
decision-makers in the household. Indeed, a second standard data requirement for this test to be performed is that all households should be composed of only two decision-makers, of opposite gender. Attanasio and Lechène (2002) address this issue by selecting a sample of households who are solely composed of two decision-makers. In rural Mexico, this is likely to be a highly selected group, as individuals live in extended families that usually include more than two decision-makers.

In this paper, unlike Attanasio and Lechène (2002), I relax the assumption that the head of household and his wife are the sole two decision-makers. I consider decision-making in the context of the extended family and propose a new test of the unitary model under the assumption that any family member who earns some income may contribute to decision-making. The test is as follows: under the unitary model conditions, any change in the number or identity of income earners should not lead to changes in nutrition, when one accounts for the changes in household income and size. The main contribution of this paper to the existing literature is to estimate the effect of a change in the intrahousehold distribution of income in the context of the extended family and to propose a novel way of evaluating the validity of the unitary model. The other contribution of the paper is to evaluate the two dominant models of household decision-making under the more restrictive assumption that the husband and the wife are the sole two decisionmakers. Because of the social experiment, the treatment effect of PROGRESA acts as an exogenous shock to women's and household's incomes. In the two decision-makers setting, characteristics of the spouses' families at the time of marriage are used as additional identifying restrictions in order to correct for the endogeneity issues between spouses' incomes and calories.

\footnotetext{
${ }^{6}$ See http://www.ifpri.org/themes/progresa.htm for detailed data description and impact analysis.
} 
There are three main findings to this study. First, under the stronger assumption that only the head of household and his spouse participate in decision-making, both the income pooling restriction and the Pareto-efficiency assumption are rejected for the nutrition decisions for families. As most studies fail to reject the collective model assumption, I discuss potential theoretical and empirical reasons for the result obtained in this study. ${ }^{7}$ Second, when I relax the assumption that there are only two decision-makers in all households, I still reject the unitary model. I find that calorie consumption increases by $19 \%$ when a woman starts earning income and decreases by $10 \%$ when it is a man who starts earning income, after accounting for the change in household income. The asymmetry of effects points out to different preferences of men and women towards household consumption of food. Third, the impact of the intrahousehold distribution of income is both statistically and substantively relevant in the extended family context while it is only statistically significant but substantively small in the two decision-makers setting. This suggests that the case for targeting benefits to specific household members lies in understanding the nature of decision-making in extended families. This paper is a first step in this direction.

The paper is organized as follows. In the following section, I describe the PROGRESA program, the experimental evaluation sample and the sample used in this study. In the third section, I present the empirical models, the tests of income pooling and the test of Paretoefficiency in the context of the nutrition decisions. In the fourth section, I review the empirical issues and present the estimation strategy adopted. In the fifth part, I discuss the findings. In the last section, I conclude.

\footnotetext{
${ }^{7}$ Exceptions are work by Udry (1996) and Duflo and Udry (2004) that I discuss later in this paper.
} 


\section{The Data}

\subsection{Description of the PROGRESA program}

I rely on data collected for the evaluation of the Mexican program for education, health and nutrition, PROGRESA. The PROGRESA program targets poor rural households in Mexico. It has been implemented since 1998. At the end of 1999, it covered 2.6 million families, i.e., about $40 \%$ of all rural households and one ninth of all families in Mexico. In 1999, the program's annual budget was approximately $\$ 777$ million, which corresponds to 0.2 percent of Mexico’s GDP (Skoufias, 2001). In January 2002 the Inter-American Development Bank approved its largest loan ever to Mexico for expanding PROGRESA to urban areas of the country. Despite political changes, PROGRESA has been maintained under the new name Opportunidades.

A baseline census of households provides the information used to determine the eligibility status of the households. Basically, a poverty line is drawn and only households below the poverty line are classified as eligible for program benefits. Among eligible households, less than $30 \%$ live in a house where the floor is made of cement or have access to piped water. On average, 78 percent of each locality's population are found to be poor, that is, eligible for the program benefits.

The program provides educational grants as well as a bimonthly monetary transfer to beneficiary households. Educational grants are given to families with children in the last three years of primary school and secondary school children. The grant amounts vary by grade and gender, with greater awards to girls and to the most advanced children. The grants are given upon attendance to school. A complex system of verification based on forms completed and signed by teachers and school directors ensures that the attendance requirement is met before 
sending money to the households. All eligible households can benefit from a monetary transfer designed to help them improve their nutrition. They are encouraged to spend the money on food although not required to do so. In order to receive this cash transfer, they are required to make regular visits to health centers and to participate in health talks. Only one visit per year to a health center is required for adults, two to five visits a year for pregnant and breast-feeding women and two to seven visits a year for infants and children. In addition, nutritional in-kind supplements are provided to under-nourished children and infants and pregnant and breastfeeding women.

A relevant characteristic of the PROGRESA program with respect to this study is that transfers are made to the mother in the household. The transfer is relatively large. For instance, the average transfer from October 1998 to November 1999 is about 197 pesos per household per month, which is equivalent to $20 \%$ of the mean value of consumption of a poor household. ${ }^{8}$

\subsection{Experimental design for the evaluation of PROGRESA}

The evaluation study is designed as an experiment with localities randomly assigned to treatment and control groups. Only eligible households in treatment localities receive benefits after the start of the program in mid-1998. All non-eligible households, as well as eligible control group households, do not receive benefits. The sample includes 506 localities (320 assigned to the treatment group and 186 to the control group).

The evaluation dataset consists of repeated observations for about 24,000 eligible and non-eligible households over 5 rounds of survey (baseline: October 1997 and March 1998; follow-ups: November 1998, June 1999 and November 1999). Data are collected to capture the multiple objectives of the program in terms of human capital investment and poverty alleviation.

\footnotetext{
${ }^{8}$ The figures are in November 1998 pesos and the value is approximately \$20 US.
} 
The last three surveys collect both household-level expenditure and individual-level labor activities and non-labor income (Table 1). In addition, a module was specially designed to get information on the status of women and on intrahousehold relations. ${ }^{9}$ I also use administrative data on the actual PROGRESA transfers received by beneficiary households in the treatment group in 1998, prior to the November 1998 survey.

\subsection{Sampling frame}

In order to measure the effect of the distribution of income on nutrition outcomes, I use two datasets. The November 1998 cross-section focuses on households with two decisionmakers. Longitudinal data from November 1998, June 1999 and November 1999 allows me to study decision-making in extended families.

The two decision-makers setting relies on the assumption that, even when household members other than the head of household and his spouse earn income, the sole two decisionmakers are the head and his spouse. ${ }^{10}$ This is a strong assumption, which is relaxed in the extended family setting. The extended family setting allows every household member who earns income to participate in decision-making.

The November 1998 survey is collected for 24,073 households (136,250 individuals). I select 20,925 households for which there is an intact couple. I restrict the sample to 17,382 households with a male head of household and his wife who are more than 15 years old and who report some income (labor earnings or non-labor income) and consumption data.

\footnotetext{
${ }^{9}$ For a description of the module on women's status and intrahousehold relations, see Adato et al. (2000).

${ }^{10}$ Note that another way of defining two decision-maker families is to restrict the sample to households where only the husband and/or the wife earn income. Yet, this means restricting the sample based on a variable that may be affected by the PROGRESA treatment, namely having an additional earner in the family. Indeed, when comparing the fraction of the treatment and control groups that are dropped when applying this restriction to the sample, I find that respectively $34 \%$ of the control group households and $25 \%$ of the treatment group households are dropped. Thus, I do not apply this restriction to the data. Instead, I impose the assumption that only the head of household and his spouse participate in decision-making.
} 
In the end of 1998, a new computation of the poverty line led to the inclusion in the eligible population of 899 households who were previously ineligible for program benefits. This process is referred to as the "densification" process. It affected all eligible localities enrolled in the PROGRESA program. I exclude these households from the analysis because they have not yet received the program benefits at the time of the November 1998 survey although they probably anticipate becoming eligible.

The partition between the treatment and the control group and the eligible and noneligible groups for the remaining 16,483 households is given in Table 2. I restrict the sample further to the 9,223 households who are eligible to program benefits. This restriction is justified by the identification strategy used in the empirical section. Table 3 presents descriptive statistics for the variables in the selected sample.

Longitudinal data from November 1998, June 1999 and November 1999 are used to study decision-making for extended families. In all three rounds, data are collected on household nutrition, consumption, labor activities and income. In contrast to the 1998 cross-section sample, I keep all households for which consumption data are reported, including eligible and noneligible households. There are a total of 18,790 households in each round. Changes in the number of individuals earning income are shown in Table 4. Table 5 shows other descriptive statistics for this dataset.

\subsection{Expenditures, Nutrients and Incomes}

Food expenditures include household level data on food outlays made in the seven days preceding the interview for 36 food items. The value of food consumed from own production in that same period of time is added to food outlays to obtain the value of food consumption. Food consumed from own production is valued by imputing either a household-level price or a locality 
level price when the household does not report any expenditures on the food consumed from own-production. Non-food expenditures are expenses reported on a weekly, monthly and semiannual basis. Non-food expenses reported on a weekly basis include transportation and tobacco. Monthly outlays include school tuition, health-related expenses, home cleaning, electricity and home fuel expenditures. Expenditures reported on a semi-annual basis include home and school supplies, clothes, shoes, toys and payments for special events. The value of consumption is computed as the sum of non-food expenditures and the value of food consumption.

The measure of food calories consumed is constructed from the 7-day recall food consumption data. First, the units of the 36 food items bought and consumed in the household are converted into kilograms. The second step is to calculate for each food item the "edible" kilograms of food. The edible kilograms are converted into kilocalories. ${ }^{11}$ Lastly, instead of dividing this total household calorie consumption by the number of household members, an adjustment is made for the fact that some household members ate outside the home and some non-household members ate in the home during the study period. This adjustment consists in subtracting from household size the number of people having food outside and adding the number of people eating in the household. Thus, the aggregate food calories are represented by the daily per mouth measure of food calories consumed. I also consider aggregate calories consumed from four different food groups, i.e. calories from vegetables and fruits, calories from grains and cereals, calories from meat and meat products and calories from other food. Average per mouth daily calorie consumption is 2070 , of which 1610 comes from the consumption of cereals and grains and 41 from vegetables and fruits.

\footnotetext{
${ }^{11}$ All conversions are based on Mexican food tables from Tablas de Valor Nutritivo de los alimentos de mayor consumo en Mexico (1996).
} 
The income data are comprised of labor and non-labor incomes. Labor income is constructed using wages and the value of employer-provided benefits from all activities. Most of the individuals work as agricultural workers paid on a daily basis. The second most common type of occupation for heads of household is self-employment. ${ }^{12}$ Respondents are probed several times in the questionnaire to elicit all labor earnings. In particular, a section of the survey directly concerns more informal types of activities such as sewing and craft-making, cooking and homecleaning, building, repairs and driving. Non-labor income is comprised of pensions, bank interest, rents and other revenues, government transfers and remittances. I also include the actual PROGRESA transfers in the wife's non-labor income for beneficiary households in the treatment communities. The average monthly transfer actually received by the women is about 125 pesos (in 1998 figures). This figure is about three times less than the payment women are entitled to and which is computed using the program rules and household composition. Much of the difference between actual and hypothetical payments comes from operational problems in transfer delivery (Coady and Djebbari, 1999).

In the extended family analysis, any individual who earns some labor or non-labor income is considered as an income earner. There are in average 1.6 income earners per household. Respectively $64 \%$ of wives and $97 \%$ of heads of household earn any income in November 1998. The number of income earners changes when household members enter or exit the labor force, start or stop receiving non-labor income. The number of earners also changes when one income earner joins the household or leaves the household (Table 4). More than half of the households did experience a change in the number of household earners in both periods.

\footnotetext{
${ }^{12}$ Detailed information on agricultural activities is also collected. Net profits computed as the difference between sales of agricultural products and expenses on inputs are negative for most of the respondents. In addition, it is far from straightforward how to assign the agricultural profits to individuals. Thus, reported income from selfemployment is the preferred measure of income from agriculture for non-wage-earner farmers.
} 


\section{Empirical model}

\subsection{Two decision-makers setting}

The unitary model embodies an important assumption with regards to household preferences. A household is assumed to behave "as one". This occurs if all household members have the same preferences or if one household member imposes his preferences, acting as a dictator. The only economic justification for the unitary model is Becker's Rotten Kid Theorem (Becker, 1974), which holds under restrictive conditions (Bergstrom, 1989). A testable implication of the unitary model is as follows: once you condition on household expenditures, individual incomes should not have any effect on demand. When this is rejected, individual income acts as a distribution factor, i.e. a factor that shifts the power within the household but does not affect household preferences or technology directly, nor the budget line.

In contrast to the unitary model, the collective model recognizes that household members have different preferences and only imposes Pareto-efficiency on the allocation decision. Under the assumption that the head of household and his spouse are the sole two decision-makers in the household, testing the collective rationality requires the use of two distribution factors and several goods. The distribution factors only affect consumption of a good through their effect on the factor weighting the utility function of each partner in the household objective function. Thus, Pareto-efficiency can be empirically verified by testing the hypothesis that the ratio of the effects of the two distribution factors across pairs of goods is constant.

Following Browning and Chiappori (1998) and under the assumption that only the head of the household and his spouse participate in decision-making, I estimate two distinct models for the demand for food: a restricted collective model and an unrestricted collective model. In both models, the dependent variable is a measure of food calories consumed by the household. 
Independent variables include the value of consumption, which is used as a proxy for household wealth (Deaton, 1997) ${ }^{13}$ as well as prices, household and village characteristics. The restricted collective model includes only one distribution factor whereas the unrestricted one models a system of demand equations for four distinct food categories and includes two distribution factors. I consider the extended family setting in the next sub-section.

The restricted collective model includes the log of the wife's non-labor income as a distribution factor. ${ }^{14}$ Since PROGRESA targets transfers to women, as much as $62 \%$ of women have some non-labor income. As for labor earnings, only 5\% of women earn any income in the labor market. ${ }^{15}$ The restricted model is as follows:

$$
\ln C a l=\alpha+\beta \ln P C E+\gamma \ln W N L Y+Z \theta+\varepsilon,
$$

$\ln C a l \quad$ is the log of per mouth household calorie consumption, $\ln P C E \quad$ is the log of per capita value of consumption, $\ln W N L Y \quad$ is the log of wife's non labor income, $\mathrm{Z} \quad$ is a vector of household and locality characteristics, $\varepsilon \quad$ is the error term, $\alpha, \beta, \gamma, \theta$ are parameters to be estimated.

Prices of the ten most commonly consumed food items, i.e. tomatoes, onions, maize tortillas, noodle, rice, beans, eggs, coffee, sugar and vegetable oil, are included in the $Z$ vector. ${ }^{16}$ Household size and household composition are included to capture the effect of economies of scale. ${ }^{17}$ Households derive utility not only directly from nutrition, but also from the effect of nutrition on health. Thus, I add household and village characteristics that affect the production of health and nutrition (e.g. presence at the locality level of health facilities, access to a sewage

\footnotetext{
${ }^{13}$ Since the PROGRESA program targets the poorest households, the sample is homogeneous in terms of income. Thus, unlike Strauss and Thomas (1990) and Bhalotra and Attfield (1998), I ignore non-linear income effects.

${ }^{14}$ Note that one peso is added to incomes when taking a logarithmic transformation. The logarithmic transformation of the dependent and independent variables allows interpreting the coefficients as elasticity measures.

${ }^{15}$ In contrast, only $34 \%$ of men have some non-labor income, but as much as $88 \%$ of them earn some labor income.

${ }^{16}$ At least $50 \%$ of the sample reported some consumption of each of these food items.

${ }^{17}$ Household composition is described using the number of individuals in different age and gender groups.
} 
system and to electricity, husband's years of education and wife's years of education). Husband's education and wife's education are also likely to capture taste differences between households. If they are not included, these variables would be absorbed into the error term and would likely generate spurious correlation between the error term and the income variables.

The unrestricted collective model for calories consumed includes husband's earnings as an additional distribution factor. Four distinct food groups are considered: vegetables and fruits, cereals and grains, meat and meat products and other food. The purpose of estimating this model is to test of the collective rationality on the nutrition outcomes. The unrestricted model is as follows:

$$
\forall k: \quad \ln C a l^{k}=\alpha^{k}+\beta^{k} \ln P C E+\gamma_{1}^{k} \ln W N L Y+\gamma_{2}^{k} \ln H L Y+Z \theta^{k}+\varepsilon^{k},
$$

$k \quad$ indicates the food category,

$\ln \mathrm{Cal}^{k}$ is the log of per mouth household calorie consumption from food group $k$, $\ln P C E$ is the log of per capita value of consumption, $\ln W N L Y$ is the log of the wife's non labor income, $\ln H L Y \quad$ is the log of the husband's labor income, $\mathrm{Z} \quad$ is a vector of household and locality characteristics, $\varepsilon \quad$ is the error term, $\alpha, \beta, \gamma_{i}, \theta$ are parameters to be estimated.

Note that for any differentiable monotonic function $\phi($.$) of A^{i}$, we have:

$$
\begin{array}{ll}
\forall k, l: & \frac{\partial X_{k} / \partial \phi\left(A^{1}\right)}{\partial X_{k} / \partial A^{2}}=\frac{\partial X_{l} / \partial \phi\left(A^{1}\right)}{\partial X_{l} / \partial A^{2}} \\
\forall k, l: & \frac{\partial X_{k} / \partial A^{1}}{\partial X_{k} / \partial \phi\left(A^{2}\right)}=\frac{\partial X_{l} / \partial A^{1}}{\partial X_{l} / \partial \phi\left(A^{2}\right)}
\end{array}
$$

Therefore, it should not matter, for testing the Pareto-efficiency assumption, whether husband's and wife's incomes enter in level or in logarithms as long as they enter all equations for the four food groups in the same way. 


\subsection{The extended family setting}

Most of the literature on intrahousehold bargaining focuses on families with two decision-makers. ${ }^{18}$ In the extended family setting, I assume that any income earner participate in household decision-making. In this case, the standard test of income pooling would require using all individual incomes. Because of the lack of variation in the income data, this could lead to very imprecise estimates for each individual income effect.

Instead, I rely on the fact that in the unitary model of household behavior, for a given budget constraint, the number of income earners should not affect the allocation of resources. I exploit this restriction in order to test the unitary model in the extended family context with longitudinal data. The dependent variable is the per mouth amount of calories consumed in the household. The explanatory variables include per capita value of consumption, a time trend, household size, household composition and other time-constant household characteristics, such as husband's and wife's education.

The estimation is based on a first-difference model that relates changes in calorie consumption to changes in the number of income earners. The first-differencing transformation is denoted by $\Delta$, and is equal to the change from period $(t-1)$ to period $t$ of the variables of interest. The first round of data is lost in the transformation, leaving us with two time periods for each observation. But, this transformation allows correcting for any fixed unobserved effect and does not impose that error terms are serially uncorrelated. Any time-invariant explanatory

\footnotetext{
${ }^{18}$ Exceptions include Dauphin and Fortin (2001) Dauphin, El Lagha, Fortin and Lacroix (2004a) and Dauphin, Fortin and Lacroix (2004b). The purpose of these studies is two-fold: (1) to test the collective assumption, for a given number of decision-makers, (2) to determine the number of decision-makers once the collective rationality is imposed. Dauphin and Fortin (2001) provide the theoretical basis for determining the number of decision-makers in an extended family under the collective rationality condition. Dauphin et al. (2004a) extend the framework and applies it to British families composed of a couple and a child aged 16 and above who are all working. Dauphin et al. (2004b) apply it to polygamous households in Burkina Faso.
} 
variable is also differenced away. I estimate two specifications for this model. The first specification is as follows:

$$
\begin{array}{cl}
\Delta \ln C a l=\alpha+\beta \Delta \ln P C E+\gamma \triangle N E A R N E R S+\Delta Z \theta+\Delta \varepsilon, & \\
& \text { is the log of per mouth household calorie consumption, } \\
\ln C a l & \text { is the log of per capita value of consumption, } \\
\ln P C E & \text { is the number of individuals earning some income, } \\
\mathrm{Z} & \text { is a vector of household characteristics, } \\
\varepsilon & \text { is the error term, } \\
\alpha, \beta, \gamma, \theta & \text { are parameters to be estimated. }
\end{array}
$$

Equation (4) includes the number of individuals in the household earning any income.

The second specification is richer as it includes as explanatory variables the number of male household members who started earning income, the number of male household members who stopped earning income, the number of female household members who started earning income, and the number of female household members who stopped earning income between two successive periods. The second specification is based on the following equation:

$$
\begin{array}{cl}
\Delta \ln C a l=\alpha+\beta \Delta \ln P C E & +\gamma_{m e} \Delta \text { Nmenter }+\gamma_{f e} \Delta N \text { fenter } \\
& +\gamma_{m d} \Delta N m \text { drop }+\gamma_{f d} \Delta N f d r o p+\Delta Z \theta+\Delta \varepsilon, \\
& \text { is the log of per mouth household calorie consumption, } \\
\ln C a l & \text { is the log of per capita value of consumption, } \\
\ln P C E & \text { is the number of male who starts earning some income, } \\
\Delta N \text { menter } & \text { is the number of male who stops earning some income, } \\
\Delta N \text { mdrop } & \text { is the number of female who starts earning some income, } \\
\Delta N \text { fenter } & \text { is the number of female who stops earning some income, } \\
\Delta N f d r o p & \text { is a vector of household characteristics, } \\
Z & \text { is the error term, } \\
\varepsilon & \text { are parameters to be estimated, } g=m e, f e, m d, f d .
\end{array}
$$

Equation (5) allows distinguishing the effect of an additional female earner from the effect of an additional male earner, as well as the effect of a household member who starts earning income from the effect of a household member who stops earning income. 


\subsection{Testing models of household behavior}

\subsubsection{Testing the unitary model}

If one believes that only the head of household and his spouse contribute to decisionmaking then the restricted collective model (1) allows testing whether the unitary model holds for total calories consumed. One would test whether, once you condition on household expenditures, the wife's non-labor income affects the quantity of calories consumed by the household. Thus, the test is based on the following null hypothesis:

$$
\boldsymbol{H}_{0}: \gamma=0 .
$$

The restricted collective model (1) can also be used to test the unitary model restriction for the demand for calories from each food group. Alternatively, the unrestricted collective model (2) provides a basis for testing the unitary model restriction for the calories consumed from any food group. Similar tests have been proposed in the literature for different $X$ outcomes. The most common outcomes include a system of budget shares for different categories of goods $^{19}$ and health status of children. ${ }^{20}$

\footnotetext{
${ }^{19}$ Thomas (1993) finds a differential effect of individual incomes on budget shares for urban Brazil. Bourguignon, Browning, Chiappori and Lechène (1993) find similar evidence from French data using individual incomes and total household income. Hoddinott and Haddad (1995) using data from Cote-d'Ivoire show that the wife's share of income significantly affects budget shares. Doss (1996) finds that household budget shares in Ghana depend on the share of current assets held by women. Browning and Chiappori (1998) reject the unitary model of the household with Canadian data on budget shares and individual incomes. Attanasio and Lechène (2002) find that the wife's share of income significantly affects the budget shares based on the PROGRESA data.

${ }^{20}$ Thomas (1990) finds a differential effect of individual incomes on anthropometric measures for children and children's survival probabilities in urban Brazil. Haddad and Hoddinott (1994) find an effect of the wife's share of income on anthropometrics of Ivorian children. Thomas (1994) presents evidence for urban Brazil, urban Ghana and the U.S. of an effect of parents' education on child health. Thomas, Contreras and Frankenberg (2002) provide evidence of a differential effect of assets brought at time of marriage by the father and the mother on child health. Duflo (2003) finds that the presence of an elderly woman eligible for an old-age pension plan is associated with a large impact on the health of girls residing in the same household. This effect is negligible for elderly men on both girls and boys residing in the same household. Concerning household nutrition, Thomas (1990) finds a differential effect of husband's income and wife's income on the per capita intakes of calories and proteins with data from urban Brazil.
} 
In contrast, in the extended family setting, testing the unitary model restriction consists in testing the hypothesis that changes in the number of income earners do not affect on changes in calorie demand conditional on changes in consumption and family size. Based on equation (4), the hypothesis is as follows:

$$
H_{0}: \gamma=0
$$

Based on equation (5), it is as follows:

$$
H_{0}: \gamma_{f d}=\gamma_{f e}=\gamma_{m d}=\gamma_{m e}=0 .
$$

Equation (8) states that neither the number of income earners in the household nor their identities should affect the demand for food for a given household income.

\subsubsection{Testing the Pareto-efficiency assumption}

Testing the Pareto-efficiency assumption requires the estimation of the unrestricted collective model (2) for the various food groups. In order to test for Pareto-efficiency in a joint manner for the calories consumed from the different food groups, a Wald test is computed for the following non-linear restrictions:

$$
\begin{aligned}
\boldsymbol{H}_{\boldsymbol{0}}: & \gamma_{1}^{1} \times \gamma_{2}^{2}-\gamma_{2}^{1} \times \gamma_{1}^{2}=0 \\
& \gamma_{1}^{2} \times \gamma_{2}^{4}-\gamma_{1}^{4} \times \gamma_{2}^{2}=0, \\
& \gamma_{1}^{3} \times \gamma_{2}^{4}-\gamma_{1}^{4} \times \gamma_{2}^{3}=0
\end{aligned}
$$

Under the null hypothesis, the Wald test is asymptotically distributed as a chi-square with three degrees of freedom. Rejecting the joint null hypothesis is a rejection of the Paretoefficiency assumption underlying the collective model. 
Most of the literature fails to reject the collective rationality. ${ }^{21}$ Yet, using data from subSaharan Africa on agricultural production decisions for plots operated by men and women living in the same household, Udry (1996) rejects the Pareto-efficiency assumption underlying the collective models. He explains the inefficiency as the consequence of missing markets in land, labor and/or assets in Ghana. Similarly, expenditure patterns of households in Cote d'Ivoire are found to be Pareto-inefficient (Duflo and Udry, 2003). According to the authors, the allocation of resources is dictated by social norms. The inefficiency arises because of the lack of cooperation in the household generated by information asymmetries and/or enforcement problems.

Pareto-inefficient decisions can arise from a cooperative game with non-cooperative threat points. In Lundberg and Pollak (1993) separate sphere bargaining model, each spouse is responsible for making decisions on different goods. In the inefficient equilibrium, family public goods are under-supplied because of the lack of coordination between the individual household members. Yet, the supply of public goods is higher when traditional gender roles serve as a focal point for the division of responsibilities than when household members act as independent optimizing individuals. Pareto-efficient outcomes could emerge from cooperative bargaining if the transaction costs related to the negotiation, monitoring and enforcement of the agreements between household members are low compared to the benefit of moving from the traditional gender role equilibrium to a Pareto-efficient equilibrium.

\footnotetext{
${ }^{21}$ Bourguignon, et al. (1993) find that the ratio of the effects on commodity demands of each household member's individual income are constant across goods using data on French households in which both spouses work full time and have at most one child. Thomas and Chen (1994) provide similar evidence for households in Taiwan. Browning and Chiappori (1998) use the log of the ratio of wife's earnings to husband's earnings and the wife's log earnings as the two distribution factors to test for Pareto-efficiency in a budget shares system for Canadian households. They cannot reject Pareto-efficiency. Thomas, Contretas and Frankenberg (2002) provide evidence that Indonesian households make Pareto-efficient decisions with respect to children's health. They consider the value of assets brought to marriage by each spouse as the two distribution factors affecting the distribution of power within the household.
} 
Finally, the collective rationality is rejected when one assumes a lower number of decision-makers than what actually is. Using British data on married couples living with one child over 16 years old who are all working, Dauphin, El Lagha, Fortin and Lacroix (2004a) rejects Pareto-efficiency with one or two decision-makers, but not when three decision-makers are assumed.

\section{Estimation strategy}

In this section, I discuss the empirical issues that arise when estimating the models described above. The issues concern both the effect of the value of consumption and the effect of the individual incomes on nutrition outcomes. These effects are likely to be inconsistently estimated by OLS. In the light of other work in this area, I propose an empirical strategy to correct for the biases and discuss remaining potential pitfalls.

\subsection{Value of consumption}

In all models, I treat the value of consumption as endogenous. There are three possible sources of endogeneity. First, when the total value of consumption is used to capture household wealth, then any measurement error in the food quantity data can be found in food calories (the dependent variable) as well as in the value of consumption (the explanatory variable). Thus, a problem of common measurement error arises. Second, data usually over-estimate consumption for rich households, because they include consumption by non-household members (e.g. employees) and usually under-estimate consumption for poor households, whose members often eat on the workplace (e.g. agricultural workers, domestic workers). The error term in the equation for calories consumed is then correlated with household wealth. Third, another potential endogeneity issue can rise from the existence of a feedback effect from nutrition to income, as described in the efficiency wage literature (Stiglitz 1976). 
Part of the spurious correlation is corrected for using a strategy similar to Subramanian and Deaton (1996). Instead of dividing the value of consumption by household size, I divide it by the actual number of individuals who regularly eat in the household and obtain a per mouth value of consumption. In order to correct for endogeneity from common measurement error, I use per capita household income as an instrument. It is highly correlated with the value of consumption and uncorrelated with the measurement error. Because endogeneity can also arise from a feedback effect, I use dwelling characteristics as instruments. The dwellings attributes I focus on are the type of material the floor is made of and the house access to piped water. Definitions of the variables and descriptive statistics are given in Table 3. They are also correlated with the value of consumption but unlikely to be correlated with the unobserved determinants of nutrition.

\subsection{Individual incomes}

Three main empirical issues arise in estimating the effect of the intrahousehold distribution of income. First, it is difficult to argue that the individual incomes are exogenous with respect to the outcome of interest. In the context of developed countries, researchers usually avoid this issue by restricting their sample to couples where both partners are full-time workers. If most of the variation in labor supply occurs between occupations, controlling for the occupations of husbands and wives becomes a mean to hold labor supply constant across households. In the case of developing countries, restricting the sample to couples where both spouses work full-time would lead to very selective samples. ${ }^{22}$ Second, the differential effect of male and female incomes can be driven by different measurement errors in male and female

\footnotetext{
${ }^{22}$ The endogeneity issue concerns labor income and to a lesser extent non-labor income It is plausible that decisions on labor supply and consumption are made jointly. Similarly, non-labor income, which is often comprised of pensions, represents the outcome of past labor supply choices. Differential effects of husband's earnings and wife's earnings could be consistent with the unitary model. For example, Phipps and Burton (1998) find that expenditures on restaurant meals respond more strongly to the wife's income than to the husband's income. Lundberg and Pollak (1996) re-interpret this finding as a price effect.
} 
incomes. This issue raises concerns about the interpretation of the results, since different income effects may then only be due to different measurement errors each individual income (Haddad 1999). Third, the data are usually concentrated in certain regions of the joint distribution of husband's income and wife's income. In particular, in most developing countries datasets, as in the PROGRESA control localities, women have little income. Some combinations of male and female income, such as high female income-low male income, are unlikely to be found in the data. Thus, a problem of support arises. This means that there is little variation to parametrically identify and single out the effects of husband's income and wife's income, making identification of the effects difficult. Because PROGRESA gives income to women in the treatment group, this dataset is useful for examining the role of the mother's income in household decisions.

In the restricted collective model, I treat women's non-labor income as endogenous. The identification strategy is based on the targeting of benefits to mothers in treatment group localities. Eligible mothers in the treatment group localities receive cash payments from the program that are not provided to women in the control group localities during the evaluation period. Thus, belonging to the treatment group results in higher household expenditures and higher women's income and is uncorrelated, by design, with the error term in the calorie equation (1). Belonging to the treatment group qualifies as a valid instrument for the log of wife's non-labor income and for expenditures. As in the unitary model specification, dwelling characteristics and total household income are used as exclusion restrictions in order to identify the effect of expenditures.

In the unrestricted collective model, value of consumption and spouses' income are treated as endogenous. The targeting of benefits to women in the treatment group, household total income and dwelling characteristics are used as instruments. Additional variables from a 
specific module on the spouses' families at time of marriage are used as instruments for the spouses' incomes. They include indicators of the families' social status at the time of marriage. Belonging to families of higher social status is likely to result in higher individual income and is unlikely to be correlated to the error term in the calorie equation (2).

Note that the test of Pareto-efficiency described in equation (9) is based on a non-linear hypothesis. The power of the Wald test may be limited, especially when an efficient estimator is not used. The precision of 2SLS estimates is related to the correlation between the endogenous variable and the instruments, as shown below:

$$
\begin{aligned}
& \text { Est. } \operatorname{Var}\left(\gamma^{I V}\right)=s^{2}\left[X^{\prime} W\left(W^{\prime} W\right)^{-1} W^{\prime} X\right]^{-1}, \\
& \gamma^{I V} \text { is the IV estimate for the effect of the distribution factors, } \\
& s^{2} \text { is the estimate for } \sigma^{2}, \\
& X \text { is the set of exogenous variables, } \\
& W \text { is the set of instrumental variables. }
\end{aligned}
$$

A strong correlation between $X$ and $W$ is associated with more precise IV estimates of the effects of the distribution factors. In the opposite, the use of weak instruments may lead to a failure to reject the null hypothesis of Pareto-efficiency when it is false.

In the extended family framework, panel-data are used. The first-difference model corrects for any unobserved fixed effect (Wooldridge, 2002). Yet, common measurement error, a feedback effect from nutrition to household expenditures or the number of income earners, as well as the omission of any time-varying variable related to these variables could lead to inconsistent estimates. A test of the strict exogeneity assumption is based on the fact that no subset of the explanatory variables, in levels, should enter the first-difference model. Based on specification (4), the test of exogeneity is as follows:

$$
\begin{aligned}
& \Delta \ln C a l=\alpha+\beta \Delta \ln P C E+\beta^{\prime} \ln P C E+\gamma \Delta N E A R N E R S+\gamma^{\prime} N E A R N E R S+\Delta Z \theta+\Delta \varepsilon, \\
& \boldsymbol{H}_{\boldsymbol{0}}: \beta^{\prime}=\gamma^{\prime}=0 .
\end{aligned}
$$


Note that the test is based on the assumption that expenditures enter linearly in the equation. Rejecting the null hypothesis provides evidence of a contemporaneous correlation between the explanatory variable and the error term. If the test rejects the null, one can estimate the first-difference equation (4) using 2SLS rather than OLS to correct for the endogeneity. A set of valid exclusion restrictions includes any of the other explanatory variables in levels, provided that there are sufficiently correlated with the endogenous variables.

Using the same Mexican dataset I use in this study, Attanasio and Lechène (2002) test the income pooling restriction in a budget shares system that includes food, alcohol and tobacco, transportation, services, woman's clothing, men's clothing, girl's clothing and boy's clothing. Yet, on average, $97 \%$ and $95 \%$ of all households respectively report zero expenditure for alcohol and tobacco. The authors do not correct for the mass point at zero in the estimation of the budget shares system. Given the strength of censoring at zero, it is likely that the test of income pooling is based on inconsistent estimates. They exploit the exogenous change in women's income created by the targeting of the program's benefit to mothers within randomly selected treatment localities to instrument both total expenditures and the wife's share of total income as outlined above. Yet, they restrict the sample to households comprising no more than two married adults and any number of children. Since the PROGRESA treatment affects the number of adult members co-residing in the household, a selection bias arises. In this case, using the PROGRESA treatment variable as an instrument is inappropriate because it is correlated with the error term in the outcome equation. Along with the random allocation of benefits between treatment group women and control group women, the authors use village-level agricultural wages as an additional instrument in order to identify the system. Since the PROGRESA villages strongly rely on agriculture, high village-level wages are likely to occur in villages that 
experience a good harvest. People who live in these villages are also likely to have higher food consumption than people living in villages that have experienced low agricultural yields. Thus, if the village-level aggregates capture local conditions that affect nutrition in the village, using them as an identifying restriction would lead to inconsistent estimates. The authors reject the income pooling restriction in the budget shares system. They do not test the Pareto-efficiency assumption.

Rubalcava, Teruel and Thomas (2002) estimate a budget shares system similar to Attanasio and Lechène (2002) using the PROGRESA data. One of the main differences is that they split food budget share into budget shares for four categories of food, i.e. budget share for vegetables, fruits, tortilla and beans, and meat. The other equations in the budget shares are similar to the ones in Attanasio and Lechène (2002). The other main difference is methodological. The authors estimate the effect of the PROGRESA actual transfer amount controlling for total family expenditures using OLS on three separate samples, i.e. all treatment and control households, only eligible households in the treatment and control groups, and only eligible households in treatment group. They do not deal with the endogeneity problems in income or expenditures. Instead, they find that the estimates of the effect of PROGRESA cash transfers are similar in magnitude in the three samples. This finding leads them to interpret the PROGRESA transfer effect as the effect of a change in women's bargaining power rather than the effect of non-linearities in the Engel curve, or the effect of other components of PROGRESA such as the conditionality of the grant or the nutrition education from mandatory health talks. Yet, the actual PROGRESA transfer amounts sent to households are a reflection of household choice to participate and comply with program requirements. Thus, this variable, unlike the treatment dummy from the experiment, is no longer exogenous to consumption shares. Finding 
close estimates from three different samples does not guarantee that any of the estimates are consistent.

\subsection{Potential caveats}

\subsubsection{The effect of belonging to the treatment group on nutrition}

Belonging to the treatment group could impact nutrition decisions through the health talks that the households are required to attend in order to receive benefits, and not just through the raise in female's income. ${ }^{23}$ In addition, beneficiaries' food consumption could be affected by the receipt of nutritional in-kind supplements. These are given to eligible households with young malnourished children, expecting mothers and breastfeeding mothers.

To what extent is there a direct effect from belonging to the treatment group on nutrition above the female's income effect? In order to assess this problem, I first examine the exogeneity of the treatment group indicator in the unrestricted collective model. I use a C-test (Hayashi, 2000) to evaluate the validity of this variable as an exclusion restriction. Indeed, a C-test allows testing any subset of the orthogonality conditions, so that it supplements the standard test of over-identification. A rejection would be an indication that, taken separately, the treatment variable is not a valid exclusion restriction, i.e. that beneficiary households experience an additional program impact on food consumption beyond the effect of the cash transfer. The nature of the next checks is more qualitative. An inspection of the themes covered during the health talks suggest that the impact from the program might not be so much in term of the diversity of the diet than in terms of hygiene related diet quality, e.g. how to store food to avoid contamination by germs. Evidence from field trips also suggests that because of over-crowding

\footnotetext{
23 The health talks are held in local clinics by nurses and primary health-care practitioners. Nutrition is discussed among 25 other themes related to health such as hygiene, immunization and family planning. Emphasis is on preventive health care. Nutrition-related lectures include how to detect early malnutrition, how to get safe food, water treatment, and how to treat diarrhea by oral rehydration.
} 
in the room where talks are given, the impact of health talks on nutrition is likely to be minor. Finally, because in-kind supplements are theoretically distributed to families with young children, I compare findings on two sub-samples, i.e. "with young children" and "without young children". In particular, I compare the results from the tests of over-identifying restrictions. The idea is that the instrument is more likely to have an effect on family nutrition beyond its effect on the endogenous variables for the sub-sample "with young children" than on the sub-sample "without young children" if there is an impact from belonging to the treatment group on nutrition due to the nutritional supplements.

\subsubsection{Simultaneity in children schooling and the take-up of the program}

Since school grant money is only given to women whose children are regularly attending school, the decision to take-up the transfer and the decision to invest in children's education are made jointly. For this reason, rather than the take-up of benefits, I use the treatment indicator, i.e. an indicator of "the offer to treat". Non-participation by eligible treatment households in the program could lead to a weak correlation in the first stage equation between the endogenous variables and the instrument. Any other heterogeneity in treatment could only affect the strength of the first stage correlation. Belonging to the treatment group is an indicator of the offer to treat, which is an exogenous variable with respect to household choice. Whether households decide to send children to school or not could only affect the findings because of a weak correlation in the first stage equation between the offer to treat dummy and the endogenous variables, which can be checked using a standard t-test. The issue of simultaneity between the children schooling decision and the take-up of the program is more problematic in studies that include education spending as a separate equation in the demand system, such as Attanasio and Lechène (2002) and Rubalcava, Teruel and Thomas (2002). 


\section{Results and discussion}

This section is organized as follows. First, I discuss findings from the different models of household behavior in the setting with two decision-makers. I discuss the validity of the instruments used in the two-stage least squares estimation. Second, I examine the results in the extended family context. Third, I test the unitary model restriction and the Pareto-efficiency assumption for the nutrition decisions. Fourth, I discuss the substantive effect of changing the wife's income on food consumption.

\subsection{Two decision-makers setting}

\subsubsection{The unitary model}

The unitary model acts as a benchmark. In the unitary model, the expenditures elasticity of total calories is found to be in the range $0.27-0.32 .{ }^{24}$ It is higher for calories from meat and meat products and calories from vegetables and fruits, suggesting that meat, vegetable and fruits are more likely to be consumed than staple food as family income increases. These estimates are obtained by treating the value of consumption as endogenous. Table 6 shows three specifications that differ in terms of the instruments used and in the source of endogeneity that is corrected for. In the first panel, the only instrument that is used is per capita household income. In the second panel, I only use the dwelling characteristics as instruments. In the third panel, I use both sets of instruments and test the over-identifying restrictions. ${ }^{25}$ In this case, I cannot reject the null hypothesis that the instruments are orthogonal to the error term. In Table 7, I present the first

\footnotetext{
${ }^{24}$ For the purpose of brevity, I may use the term expenditures in place of value of consumption.

${ }^{25}$ All IV models are estimated using GMM in order to correct for heteroscedasticity. Thus, the test of over identification is based on a J-statistic (Hansen, 1982) that is distributed as a chi-square with degrees of freedom equal to the number of over-identifying restrictions.
} 
stage regressions for the three different specifications. In all three cases, the test of joint significance of the instruments in the first stage produces an F-statistic above $10 .{ }^{26}$

If the unitary model holds, then the treatment group indicator should be a valid exclusion restriction in the calorie equations. A C-test allows testing this separate hypothesis (Hayashi, 2000). Interestingly, I find that, in general, the treatment variable is not a valid exclusion restriction in the unitary model. This is the case in all of the calorie demand equations, except for meat and meat products (Table 8). It questions the unitary household model since it suggests that PROGRESA benefits are likely to have an impact on nutrition beyond the family income effect. Since benefits are targeted to women, these results could be consistent with a collective model of household behavior in which receiving PROGRESA benefits alters the balance of power within the household in favor of the women. ${ }^{27}$

\subsubsection{The collective models}

Table 9 presents the 2SLS results from the estimation of the restricted collective model. Table 10 shows the results for the unrestricted collective model.

In the restricted collective model, the estimated expenditure elasticity of total calories is 0.28. In the unrestricted collective model, this value is 0.47. As previously, the expenditure elasticity is higher for calories from meat and meat products and calories from vegetables and fruits. In general, calorie consumption increases as the wife's non-labor income increases, with the exception of the calories consumed from meat and meat products for which the effect is negative although insignificant. The effects of changes in the wife's non-labor income on calorie consumption are similar in the restricted and unrestricted collective models (Table 9 at line 2 and

\footnotetext{
${ }^{26}$ According to Staiger and Stock (1997), an F-statistic below 10 indicates weak instruments. For models with multiple endogenous variables, such a rule-of-thumb may not be informative.

${ }^{27}$ Such a finding is also consistent with an impact from the instruction provided during the health talks and/or an impact from the provision of in-kind supplements.
} 
Table 10 at line 3). In addition, in the unrestricted collective model, husband's earnings are found to have a positive but insignificant effect on the consumption of vegetables and fruits and a negative and significant effect on the consumption of meat and meat products. In the other equations, the husband's earnings elasticity is found to be small (less than 0.01) and insignificant.

In the restricted collective model, as in the unitary model, expenditures are treated as endogenous and instrumented using per capita income and dwelling characteristics. Because wife's non-labor income is treated as endogenous, the treatment dummy is used as an additional exclusion restriction. The last two lines of Table 9 provide information on the validity of the instruments. Taken jointly, all instruments are found to be valid exclusion restrictions in all equations using a test of over-identifying restrictions. The first stages are presented in Table 11. Note that the strong correlation between the instruments and the wife's non-labor income is mainly due to the treatment dummy variable.

Moreover, although in the unitary model the treatment dummy cannot be used as an exclusion restriction, I cannot reject the null hypothesis that this variable is a valid instrument in the restricted collective model, except for meat consumption. This finding suggests that the main channel through which the program affects food consumption is the increase in female's income. To supplement this finding, I compare tests of the exogeneity of the treatment dummy for households with young children (age 4 and below) and households without young children. In both cases, I cannot reject exogeneity of the treatment dummy using a C-test for one exclusion restriction. This also suggests that the effect of belonging to the treatment group on household nutrition is mainly the female's income effect, even for families with young children who are eligible for an in-kind nutritional supplement (Table 12). 
In the unrestricted collective model, expenditures, wife's non-labor income and husband's earnings are treated as endogenous. As previously, I use per capita income, dwelling characteristics and the treatment dummy as instruments. Spouses' characteristics at time of marriage are used as additional exclusion restrictions. The last two lines of Table 10 provide information on the validity of the instruments. Taken jointly, all instruments are found to be valid exclusion restrictions in all equations using a test of over-identifying restrictions. As in the restricted collective model, I cannot reject the null hypothesis that the treatment dummy variable is a valid instrument in the unrestricted collective model, except for the meat consumption. The first stage regressions for the unrestricted model are presented in Table 13. Again, the strong correlation between the instruments and the wife's non-labor income is mainly due to the treatment dummy variable.

Three conclusions can be drawn from the previous results. First, reviewing the test results for the instruments used in the estimation of the unitary model and the collective models suggests that the instruments are valid ones. Thus, the estimated effects of expenditures and individual incomes are consistent. Second, the strong correlation between the individual incomes and the instruments used for the estimation of the collective models allows the effects of the distribution factors on calorie consumption to be precisely estimated. Third, holding expenditures constant, increasing wife's non-labor income has a positive effect on total calorie consumption and increasing husband's earnings has a negligible effect on total calorie consumption but a differential effect on calories from different groups of food. 


\subsection{Extended family setting}

The sub-section is organized as follows: (1) I provide evidence of the endogeneity of the number of income earners; (2) I present the main findings on the effect of the change in the number of income earners on food consumption from a 2SLS first-difference model.

In order to test the strict exogeneity assumption, I include in the first-difference OLS regression the potentially endogenous variables in levels. The first column of Table 14 shows that, in equation (11), the number of income earners has a significant effect on the change of calories consumed, indicating an endogeneity problem. Yet, the value of consumption is insignificant. The second column of Table 16 shows that the number of male income earners and the number of female income earners have a significant effect on the change in calories consumed. Thus, I estimate the first-difference model with 2SLS using exclusion restrictions to instrument for the change in the number of income earners in equation (4), and to instrument for the number of males and females who started or stopped earning income between two successive periods in equation (5).

As mentioned above, any of the explanatory variables in levels can act as valid exclusion restrictions, provided that they are sufficiently correlated to the endogenous variable. Among these, the number of 15 to 19 year olds is found to be sufficiently correlated with the change in the number of income earners. This is consistent with teenagers being the additional income earners in the family. I use the value of per capita household income as additional exclusion restriction in equation (4). As expected, this variable is strongly correlated with the change in the number of income earners (Table 15). I test whether this additional variable is a valid instrument using a C-test of orthogonality for one exclusion restriction. I cannot reject the exogeneity of this 
particular variable. Using a standard test of over-identification, I cannot reject the exogeneity of all the instruments taken jointly (Table 16).

In equation (5), I instrument for four endogenous variables, i.e. the number of male household members who started earning income, the number of male household members who stopped earning income, the number of female household members who started earning income, and the number of female household members who stopped earning income between two successive periods. I use the same identifying restriction as in the equation (4). In addition, I use the treatment dummy, the number of 20-34 years old female household members and the number of 20-34 years old male household members. These young adults constitute a pool of income earners in the family. The use of the treatment dummy as an exclusion restriction increases the precision of the 2SLS estimates. Table 15 shows that the instruments are strongly correlated with the endogenous variables. Using a test of exogeneity for a single instrument, I cannot reject the exogeneity of the treatment dummy. In addition, I cannot reject the exogeneity of all the instruments taken jointly. These test results are reported at the bottom of the second column of Table 16.

The 2SLS estimation results for equation (4) are shown in the first column of Table 16. I find that a 1 percent change in the per capita value of consumption is associated with a 0.46 percent change in the per mouth amount of calories consumed. An additional income earner is associated with a decrease in calorie consumption on the order of 9 percent.

The extended family analysis offers two additional findings. First, the effect of an additional income earner on calorie consumption varies with the gender of the household member. Second, the effect of a household member who starts earning income is not symmetric to the effect of a household member who stops earning income, as shown in the second column 
of Table 16. When a female household member starts earning income, family calorie consumption increases by 19 percent. When it is a male household member who starts earning income, family calorie consumption decreases by 10 percent. When a female household member stops earning income, family calorie consumption decreases by 15 percent. When it is a male household member who stops earning income, family calorie consumption increases by 17 percent.

5.3 Testing the unitary model restriction and the Pareto-efficiency assumption for the nutrition decisions

\subsubsection{Testing the unitary model in the two decision-makers setting}

The unitary model is rejected in all cases except for the consumption of meat and meat products in both specifications. Table 17 provides results from testing the unitary model restriction in the restricted collective model (column 1) and the unrestricted collective model (column 2) for total calories and calories from each food group.

\subsubsection{Testing the unitary model restriction in the extended family setting}

In the extended family setting, I find a significant effect of the change in the number of income earners on changes in household calorie consumption holding changes in household expenditures and household size constant (see Table 16). Thus, in the extended family setting, the income pooling restriction does not hold. Since both the number of income earners and their gender affect the allocation of resources towards food consumption, the unitary model is rejected for nutrition decisions.

\section{$\underline{\text { 5.3.3 Testing the Pareto-efficiency assumption }}$}

Using the unrestricted collective model with two distribution factors, I reject the Paretoefficiency assumption for two pairs of goods. These consist of the pair "vegetables and fruits 
calories / cereals and grains calories" and the pair "cereals and grains calories / other food calories". The results are presented in Table 20.

If the Pareto-efficiency assumption is tested jointly over all pairs of goods, the joint hypothesis has a chi-square statistic equal to 7.14 that corresponds to a p-value of 0.094 . I reject at the $10 \%$ level the Pareto-efficiency assumption on the allocation of resources between spouses with respect to the calorie consumption decisions.

This result is consistent with the separate sphere bargaining model (Lundberg and Pollak 1993) for which gender roles assign responsibility to each partner for certain decisions. The results are also consistent with the existence of information asymmetries at the household level, or problems in the enforcement of household agreements. Finally, this result may arise because the actual number of decision-makers is not two, as I assume, but it is larger than two. In this study, I cannot distinguish between these three explanations.

5.4 How is nutrition affected by changing the intrahousehold distribution of income?

Findings presented above convey information on the statistical relevance of accounting for the effect of the intrahousehold distribution of power in modeling household decisions. Yet, as pointed out by Rosenzweig (1986), the collective models "have not provided clear directions as to how intrahousehold allocation will differ when some individual attains more bargaining strength" (p.236). I discuss the substantive importance of this effect.

According to the estimates from the restricted collective model, a 100 percent change in the wife's non-labor income is associated with a one percent change in total calories consumed. The effect is a little higher for calories from vegetables and fruits, calories from cereals and grains and calories from other food, but still in the 1 percent range. Changing the wife's nonlabor income has no effect on meat consumption. Results from the unrestricted collective model 
are consistent with these findings. In addition, the effect of husband's earnings on vegetable and fruits consumption, meat consumption and consumption of other food is found to be equal to the effect of wife's income. The negative effect of husband's earnings on consumption of cereals and grains more than offsets the positive effect of wife's income. Yet, changes in husband's income have no effect on total calorie consumption.

Overall, I find that the effects of changes in spouses' incomes are small in a substantive sense. This is consistent with recent results in the literature: "The key issue in the context of testing models of decision-making is their [statistical] significance" (Thomas 2002).

To the extent that the effect of a rise in female's income is substantively low, should we consider that the unitary model is a good approximation? There are three reasons to believe that it is not the case. First, the tests of income pooling and Pareto-efficiency that are used in this study require the inclusion of distribution factors in the model equation. However, in practice, the number and nature of the distribution factors that determine the distribution of power within the household are not clearly defined. As mentioned above, although the distribution of income is likely to affect the distribution of power within the household, other factors could also have a role. ${ }^{28}$ Omitting these factors might not affect the testing of the unitary model restriction and the Pareto-efficiency assumption. But, these other factors might have a greater impact on the distribution of power within the household than spouses' incomes. Second, most women in the sample have low income. A 100 percent change in income is a small amount in absolute terms. Thus, the support problem may play a role in the low elasticity found in this study. Third, in the extended family setting, I find that when a woman starts earning some income, family calorie consumption increases by $19 \%$. It decreases by $10 \%$ when a man starts earning income. As these

\footnotetext{
${ }^{28}$ For example, current assets and assets brought at time of marriage have been found to influence the distribution of power within the household in developing countries.
} 
effects are substantively large, ignoring the differences in preferences of household members would lead to ignore effective poverty-reducing instruments, such as those that target specific individuals in the household.

\section{Conclusion}

How does the distribution of power within the household affect the nutrition of its members? I explore this question using a unique dataset collected for the evaluation of the largest social program in rural Mexico. In this sample, poor households in randomly selected control localities did not receive program benefits until the end of the evaluation period. I exploit data from this social experiment to (1) test models of household decision-making, (2) provide some insights on how much nutrition is affected by changes in the distribution of income within the household and in the number of income earners in the household.

Focusing on the nutrition decision, I consider two settings. The first relies on the assumption that, even when household members other than the head of household and his spouse earn income, the sole two decision-makers are the head and his spouse. This is a strong assumption, which is relaxed in the extended family setting. The extended family setting allows any household member who earns some income to participate in decision-making.

In the two decision-makers setting, I reject the income pooling restriction underlying the unitary model of the household, as Attanasio and Lechène (2002) do. Yet, I find that doubling the wife's non-labor income is associated to only minor changes in calorie levels - around one percent change. Under the assumption that the sole two decision-makers are the head of household and his wife, I also reject the collective rationality. There is an allocation of resources towards consumption of the various food groups that is Pareto-superior to the one collectively chosen in the household. This result is consistent with non-cooperative decision-making. It is 
also consistent with the existence of information asymmetries at the household level. Finally, this result may arise because the actual number of decision-makers is not two, as I assume, but is larger than two. In this study, I cannot distinguish between these three explanations.

In the extended family setting, I find that, controlling for the changes in household income and size, changes in the number of income earners lead to changes in calorie consumption. This consists of a novel way of evaluating the validity of the unitary model for extended families. As in the two decision-makers case, the income pooling restriction is rejected. In contrast to the two decision-makers setting, I find substantive increases in calorie consumption when a woman starts earning income and substantive drops when it is a man who starts earning income.

From a policy standpoint, the rejection of the income pooling restriction suggests that the intrahousehold distribution of power over resources affect household decision-making. When I relax the assumption that the head of household and his spouse are the sole two decision-makers, I find that the implications of the unitary model do not hold for extended families in poor rural regions of Mexico. In addition, in the extended family setting, when a woman starts earning income, family calorie consumption increases by 19 percent. This is in contrast to the findings in the two decision-makers setting, for which changes in food consumption associated with changes in the intrahousehold allocation of income are found to be small. This difference highlights the importance of taking into account the characteristics of households in poor countries in the empirical modelling of household decision-making in order to guide policy. 


\section{References}

Adato, Michelle, Bénédicte de la Brière, Dubravka Mindek and Agnes Quisumbing. 2000. "Final report: the impact of PROGRESA on women's status and intrahousehold relations." Report submitted to PROGRESA. International Food Policy Research Institute, Washington D.C.

Attanasio, Orazio and Valérie Lechène. 2002. "Tests of income pooling in household decisions." Review of Economic Dynamics. 5: 720-748.

Becker, Gary. 1974. “A Theory of Social Interactions." Journal of Political Economy. 82(6): 1063-1093.

Behrman, Jere and Anil Deolalikar. 1987. "Will developing country nutrition improve with income? A case study for rural south India." Journal of Political Economy. 95(4): 492-506.

Behrman, Jere and Petra E. Todd. 1999. "Randomness in the Experimental Samples of PROGRESA (Education, Health, and Nutrition Program)." Report submitted to PROGRESA. International Food Policy Research Institute, Washington, D.C.

Bergstrom, Theodore C.. 1989. "A fresh look at the Rotten Kid Theorem - and other household mysteries." Journal of Political Economy. 97(5): 1138-1159.

Bhalotra, Sonia and Cliff Attfield. 1998. "Intrahousehold resource allocation in rural Pakistan: a semi-parametric analysis." Journal of Applied Econometrics 13: 463-480.

Bouis, Howarth. 1994. "The effect of income on demand for food in poor countries: Are our food consumption databases giving us reliable estimates." Journal of Development Economics. 44: 199-226.

Bouis, Howarth and Lawrence Haddad. 1992. "Are estimates of calorie-income elasticities too high? A recalibration of possible range." Journal of Development Economics. 39: 333-364.

Bourguignon, François, Martin Browning, Pierre-André Chiappori and Valérie Lechène. 1993. "Intra household allocation of consumption: A model and some evidence from French data." Annales d'Economie et de Statistique. 29: 137-157.

Browning, Martin and Pierre-Andre Chiappori. 1998. "Efficient intra-household allocations: a general characterization and empirical tests". Econometrica. 66(6): 1241-1278.

Chiappori, Pierre-André. 1988. "Rational household labor supply." Econometrica. 56(1): 63-90. 
Coady, David and Habiba Djebbari. 1999. "Process Evaluation of the Education, Health and Nutrition Program of Mexico.” International Food Policy Research Institute, Washington D.C.

Dauphin, Anick and Bernard Fortin. 2001. "A test of collective rationality for multi-person households", Economics Letters, 71: 211-216.

Dauphin, Anick, Abdel-Rahmen El-Lagha, Bernard Fortin and Guy Lacroix. 2004. "Choix de consummation des ménages en presence de plusieurs décideurs”, CIRPÉE Working paper 04-33.

Dauphin, Anick, Bernard Fortin and Guy Lacroix. 2004. "A test of collective rationality within bigamous households in Burkina Faso", Working paper, Laval University.

Deaton, Angus. 1997. The analysis of household surveys: a microeconometric approach to development policy. Johns Hopkins University Press. 26-32.

Doss, Cheryl. 1996. "Testing among models of intrahousehold resource allocation." World Development. 24(10): 1597-1609.

Duflo, Esther. 2003. "Grandmothers and granddaughters: Old age pension and intrahousehold allocation in South Africa". World Bank Economic Review. 17(1): 1-25.

Duflo, Esther and Chris Udry. 2003. "Intrahousehold resource allocation in Cote d'Ivoire: Social norms, separate accounts and consumption choices". B.R.E.A.D. Working Paper No. 16.

Fortin, Bernard and Guy Lacroix. 1997. "A test of the unitary and collective models of household labour supply." The Economic Journal. 107: 933-955.

Haddad, Lawrence. 1999. "The income earned by women: impacts on welfare outcomes". Agricultural Economics. 20: 135-141.

Haddad, Lawrence and John Hoddinott. 1994. "Women's income and boy-girl anthropometric status in the Cote-d'Ivoire". World Development. 22: 543-553.

Hansen, Lars. 1982. "Large sample properties of generalized method of moments estmators". Econometrica. 50(3): 1029-1054.

Hayashi, Fumio. 2000. Econometrics. First edition. Princeton, NJ: Princeton University press.

Hoddinott, John and Lawrence Haddad. 1995. "Does female income share influence household expenditures? Evidence from Cote-d'Ivoire". Oxford Bulletin of Economics and Statistics. 57(1): 77-95. 
Hoddinott, John, Emmanuel Skoufias and Ryan Washburn. 2000. "The impact of PROGRESA on consumption: a final report", Report submitted to PROGRESA. International Food Policy Research Institute, Washington D.C.

Hoddinott, John and Emmanuel Skoufias. 2004. "The impact of PROGRESA on food consumption", Economic Development and Cultural Change, 53 (1): 37-61.

Lundberg, Shelly and Robert A. Pollak. 1993. "Separate spheres bargaining and the marriage market." Journal of Political Economy 101(6): 988-1010.

Lundberg, Shelly and Robert A. Pollak. 1996. "Bargaining and distribution in marriage." Journal of Economic Perspectives 10(4): 139-158.

Lundberg, Shelly, Robert A. Pollak and Terence J. Wales. 1997. "Do husbands and wives pool their resources? Evidence from the United Kingdom child benefit." Journal of Human Resources. 32(3): 463-480.

Muñoz de Chávez, Miriam, José Antonio Roldán, José Angel Ledesma, Eduardo Mendoza, Adolfo Chávez, Fernando Perez-Gil, Sonia Hernández and Alejandra Chaparro. 1996. Tablas de Valor Nutritivo de los Alimentos de Mayor Consumo en México. Edición Internacional. 330 pp.

Phipps, Shelley A. and Peter S. Burton. 1998. "What's mine is yours? The influence of male and female incomes on patterns of household expenditures." Economica. 65(260): 599-613.

Rosenzweig, Mark. 1986. "Program intervention, household distribution and the welfare of individuals: modeling household behavior." World Development. 14(2): 233-243.

Rubalcava, Luis, Graciela Teruel and Duncan Thomas. 2002. "Welfare design, women's empowerment and income pooling." Mimeo.

Schultz, T. Paul. 1990. "Testing the neoclassical model of family labor supply and fertility." Journal of Human Resources. 25(4): 599-634.

Skoufias, Emmanuel. 2001. "PROGRESA and its impacts on the human capital and welfare of households in rural Mexico: A synthesis of the results of an evaluation by IFPRI". International Food Policy Research Institute, Washington D.C.

Stiglitz, Joseph E. 1976. "The efficiency wage hypothesis, surplus labour, and the distribution of income in L.D.C.s." Oxford Economic Papers. 1976. 28: 185-207. 
Strauss, John and Duncan Thomas. 1990. "The shape of the calorie expenditure curve." Discussion paper No. 595. Economic Growth Center, Yale University.

Subramanian, Shankar and Angus Deaton. 1996. "The demand for food and calories" Journal of Political Economy 104(1): 133-162.

Thomas, Duncan. 1990. "Intrahousehold resource allocation: an inferential approach." Journal of Human Resources. 25(4): 635-664.

Thomas, Duncan. 1993. "The distribution of income and expenditure within the household." Annales d'Economie et de Statistique. 29: 109-135.

Thomas, Duncan. 1994. "Like Father, Like Son; Like Mother, Like Daughter: Parental Resources and Child Height." Journal of Human Resources. 29(4): 950-988.

Thomas, Duncan and Chien-Liang Chen. 1994. "Income shares and shares of income: empirical tests of models of household resource allocations." Labor and Population Program. Working Paper Series 94-08. 29(4): 950-988.

Thomas, Duncan, Dante Contreras and Elizabeth Frankenberg. 2002. "Distribution of power within the household and child health." UCLA and Universidad de Chile. Mimeo.

Udry, Christopher. 1996. "Gender, Agricultural Production and the theory of the household." Journal of Political Economy, 104(5): 1010-1046.

Wooldridge, Jeffrey M. 2002. Econometric analysis of cross-section and panel data. The MIT Press. 93. 
Table 1: Variables in the PROGRESA sample.

\begin{tabular}{ll}
\hline Unit of observation & Variable \\
\hline Individual and household level & $\begin{array}{l}\text { Household composition, education, health, } \\
\text { paid and non-paid labor, farm activities, } \\
\text { income, expenditures, living conditions, } \\
\text { assets, decision-making within the } \\
\text { household. }\end{array}$ \\
& $\begin{array}{l}\text { Availability of services, main economic } \\
\text { activities, all prices (including wages) }\end{array}$ \\
Locality level & $\begin{array}{l}\text { Assets at marriage of the spouses, } \\
\text { education of their parents and wealth of } \\
\text { their families, current decision-making } \\
\text { padterns }\end{array}$ \\
\hline
\end{tabular}

Table 2: Partition of households in the restricted sample between eligible / non-eligible and treatment / control groups.

\begin{tabular}{|c|c|c|c|}
\hline & Treatment localities & Control localities & Total \\
\hline \multirow[t]{2}{*}{ Eligible households } & $\begin{array}{c}\text { Transfers } \\
\text { distributed after } \\
\text { August } 1998\end{array}$ & $\begin{array}{l}\text { No transfer until } \\
\text { the end of the } \\
\text { evaluation period }\end{array}$ & 9,223 households \\
\hline & 5,823 households & 3,400 households & \\
\hline \multirow{2}{*}{$\begin{array}{l}\text { Non-eligible } \\
\text { households }\end{array}$} & No transfer & No transfer & 7,260 households \\
\hline & 4,314 households & 2,946 households & \\
\hline Total & 10,137 households & 6,346 households & 16,483 households \\
\hline
\end{tabular}


Table 3: Descriptive Statistics for the November 1998 cross-section.

\begin{tabular}{|c|c|c|c|}
\hline & Sample size & "Mean & S.D. \\
\hline$=1$ if treatment group & 9223 & 0.63 & 0.48 \\
\hline Per mouth calorie consumption & 8319 & 2072 & 869 \\
\hline P.C. value of consumption & 9028 & 181 & 107 \\
\hline P.C. family income & 9136 & 201 & 122 \\
\hline Per mouth calorie consumption from vegetables and fruits & 9184 & 41 & 36 \\
\hline Per mouth calorie consumption from grains and cereals & 9048 & 1612 & 949 \\
\hline Per mouth calorie consumption from meat and meat products & 9178 & 109 & 121 \\
\hline Per mouth calorie consumption from other food & 9176 & 329 & 178 \\
\hline$=1$ if wife earns any non-labor income & 9223 & 0.62 & 0.49 \\
\hline$=1$ if wife earns any labor income & 9223 & 0.05 & 0.22 \\
\hline$=1$ if wife earns any income & 9223 & 0.64 & 0.48 \\
\hline$=1$ if husband earns any non-labor income & 9223 & 0.34 & 0.47 \\
\hline$=1$ if husband earns any labor income & 9223 & 0.88 & 0.32 \\
\hline$=1$ if husband earns any income & 9223 & 0.97 & 0.17 \\
\hline \# of household income earners other than heads & 9223 & 0.41 & 0.76 \\
\hline Wife's non-labor income if any & 5719 & 140 & 114 \\
\hline Wife's labor income if any & 451 & 711 & 392 \\
\hline Wife's total income if any & 5873 & 190 & 233 \\
\hline Husband's non-labor income if any & 3135 & 151 & 243 \\
\hline Husband's labor income if any & 8159 & 853 & 343 \\
\hline Husband's total income of any & 8955 & 826 & 389 \\
\hline$=1$ if house floor made of cement & 9223 & 0.26 & 0.44 \\
\hline$=1$ if house has access to piped water & 9223 & 0.28 & 0.45 \\
\hline$=1$ if wife lives in the same village as she lived in before her marriage & 8053 & 0.64 & 0.48 \\
\hline$=1$ if husband's father used to wear shoes before their marriage & 8053 & 0.61 & 0.49 \\
\hline$=1$ if husband's father had some primary school education & 8053 & 0.29 & 0.45 \\
\hline$=1$ if husband's mother had some primary school education & 8053 & 0.20 & 0.40 \\
\hline$=1$ if wife's father used to wear shoes before their marriage & 8053 & 0.61 & 0.49 \\
\hline$=1$ if wife's father had some primary school education & 8053 & 0.36 & 0.48 \\
\hline$=1$ if husband owned a house at the time of marriage & 8053 & 0.17 & 0.38 \\
\hline \# of household members & 9221 & 6.60 & 2.53 \\
\hline \# of children below age 4 & 9223 & 1.15 & 1.11 \\
\hline \# of children $5-10$ & 9223 & 1.44 & 1.15 \\
\hline \# of boys 11-14 & 9223 & 0.42 & 0.64 \\
\hline \# of girls 11-14 & 9223 & 0.40 & 0.62 \\
\hline \# of boys $15-19$ & 9223 & 0.35 & 0.62 \\
\hline \# of girls 15-19 & 9223 & 0.35 & 0.61 \\
\hline \# of men $20-34$ & 9223 & 0.51 & 0.57 \\
\hline \# of women 20-34 & 9223 & 0.62 & 0.58 \\
\hline \# of men 35-54 & 9223 & 0.50 & 0.51 \\
\hline \# of women 35-54 & 9223 & 0.46 & 0.51 \\
\hline \# of men 55 or more & 9223 & 0.19 & 0.40 \\
\hline \# of women 55 or more & 9223 & 0.17 & 0.40 \\
\hline Husband's \# of years of schooling & 9223 & 2.93 & 2.64 \\
\hline Wife's \# of years of schooling & 9223 & 2.74 & 2.68 \\
\hline$=1$ if husband's an ag-worker & 9223 & 0.74 & 0.44 \\
\hline$=1$ if village has access to electricity & 9223 & 0.66 & 0.47 \\
\hline$=1$ if village has a sewage system & 9223 & 0.12 & 0.33 \\
\hline$=1$ if some permanent health care facilities in the village & 9223 & 0.84 & 0.36 \\
\hline$=1$ if mobile health squad in the village & 9223 & 0.80 & 0.40 \\
\hline
\end{tabular}


Table 4: Changes in the number of earners in the longitudinal data.

\begin{tabular}{lcc}
\hline \hline Number of earners: & November 1998 to June 1999 & June 1999 to November 1999 \\
\hline Did not change & $48 \%$ & $48 \%$ \\
Increased & $19 \%$ & $36 \%$ \\
Decreased & $32 \%$ & $16 \%$ \\
\hline
\end{tabular}

Table 5: Descriptive statistics for the longitudinal sample.

\begin{tabular}{|c|c|c|c|}
\hline Variable description & Sample size & Mean & S.D. \\
\hline Change in log. of per mouth calories consumption & 36732 & -0.016 & 0.61 \\
\hline Change in log. of per capita value of consumption & 36786 & -0.011 & 0.58 \\
\hline Change in the \# of household members who earn income & 38389 & 0.095 & 0.89 \\
\hline Change in the \# of male earners in the household & 38389 & 0.046 & 0.77 \\
\hline Change in the \# of female earners in the household & 38389 & 0.050 & 0.46 \\
\hline \# of household members who stopped earning income & 38389 & 0.248 & 0.52 \\
\hline \# of household members who started earning income & 38389 & 0.343 & 0.59 \\
\hline \# of female household members who stopped earning income & 38389 & 0.082 & 0.27 \\
\hline \# of female household members who started earning income & 38389 & 0.132 & 0.34 \\
\hline \# of male household members who stopped earning income & 38389 & 0.179 & 0.38 \\
\hline \# of male household members who started earning income & 38389 & 0.214 & 0.41 \\
\hline Change in household size & 38389 & -0.040 & 0.44 \\
\hline Change in the \# of children below age 4 & 38389 & -0.036 & 0.44 \\
\hline Change in the $\#$ of children age 5 to 10 & 38389 & -0.011 & 0.41 \\
\hline Change in the $\#$ of males age 11 to 14 & 38389 & 0.005 & 0.30 \\
\hline Change in the \# of females age 11 to 14 & 38389 & 0.003 & 0.30 \\
\hline Change in the $\#$ of males age 15 to 19 & 38389 & -0.009 & 0.32 \\
\hline Change in the $\#$ of females age 15 to 19 & 38389 & -0.017 & 0.35 \\
\hline Change in the $\#$ of males age 20 to 34 & 38389 & -0.026 & 0.33 \\
\hline Change in the \# of females age 20 to 34 & 38389 & -0.018 & 0.31 \\
\hline Change in the $\#$ of males age 35 to 54 & 38389 & -0.002 & 0.22 \\
\hline Change in the \# of females age 35 to 54 & 38389 & 0.003 & 0.22 \\
\hline Change in the $\#$ of males age 55 or more & 38389 & 0.003 & 0.18 \\
\hline Change in the $\#$ of females age 55 or more & 38389 & 0.003 & 0.18 \\
\hline Per capita calorie consumption & 37655 & 2263 & 1080 \\
\hline Per capita value of consumption & 37646 & 201 & 126 \\
\hline Per capita household income & 34556 & 246 & 162 \\
\hline \# of household income earners & 38389 & 1.6 & 0.8 \\
\hline \# of male household income earners & 38389 & 1.1 & 0.7 \\
\hline \# of female household income earners & 38389 & 0.6 & 0.6 \\
\hline \# of household members & 38383 & 5.8 & 2.7 \\
\hline$=1$ if treatment group & 38389 & 0.61 & 0.48 \\
\hline Number of males age 20 to 34 & 38389 & 0.5 & 0.6 \\
\hline Number of female age 20 to 34 & 38389 & 0.5 & 0.6 \\
\hline Number of males age 15 to 19 & 38389 & 0.4 & 0.6 \\
\hline Number of females age 15 to 19 & 38389 & 0.3 & 0.6 \\
\hline
\end{tabular}

Note: Changes relates to the period between November 1998 and June 1999, and the period between June 1999 and November 1999. Descriptive statistics for the variables in levels are reported for the June 1999 and November 1999 pooled cross-sections. 
Table 6: 2SLS estimates of the elasticity of per mouth calorie consumption with respect to per capita (P.C.) value of consumption in the unitary model.

\begin{tabular}{|c|c|c|c|c|c|c|c|c|c|c|}
\hline & \multicolumn{2}{|l|}{ Total } & \multicolumn{2}{|c|}{$\begin{array}{l}\text { Vegetables and } \\
\text { Fruits }\end{array}$} & \multicolumn{2}{|c|}{ Grains and Cereals } & \multicolumn{2}{|c|}{$\begin{array}{l}\text { Meat and meat } \\
\text { products }\end{array}$} & \multicolumn{2}{|l|}{ Other food } \\
\hline & Elasticity & $\begin{array}{l}\text { Sample } \\
\text { size }\end{array}$ & Elasticity & $\begin{array}{l}\text { Sample } \\
\text { size }\end{array}$ & Elasticity & $\begin{array}{l}\text { Sample } \\
\text { size }\end{array}$ & Elasticity & $\begin{array}{l}\text { Sample } \\
\text { size }\end{array}$ & Elasticity & $\begin{array}{l}\text { Sample } \\
\text { size }\end{array}$ \\
\hline $\begin{array}{l}\text { Specification } \\
\text { (1) }\end{array}$ & $\begin{array}{l}0.319^{* * *} \\
(0.080)\end{array}$ & 8163 & $\begin{array}{l}1.590 * * * \\
(0.235)\end{array}$ & 8657 & $\begin{array}{l}0.248 * * \\
(0.120)\end{array}$ & 8794 & $\begin{array}{l}1.200 * * * \\
(0.239)\end{array}$ & 8196 & $\begin{array}{l}0.214^{*} \\
(0.129)\end{array}$ & 8816 \\
\hline $\begin{array}{l}\text { Specification } \\
\text { (2) }\end{array}$ & $\begin{array}{l}0.277 * * * \\
(0.060)\end{array}$ & 8231 & $\begin{array}{l}1.389 * * * \\
(0.136)\end{array}$ & 8728 & $\begin{array}{l}0.232 * * * \\
(0.085)\end{array}$ & 8875 & $\begin{array}{l}1.392 * * * \\
(0.156)\end{array}$ & 8268 & $\begin{array}{l}0.183 * * \\
(0.089)\end{array}$ & 8890 \\
\hline $\begin{array}{l}\text { Specification } \\
\text { (3) }\end{array}$ & $\begin{array}{l}0.294 * * * \\
(0.049)\end{array}$ & 8163 & $\begin{array}{l}1.457 * * * \\
(0.121)\end{array}$ & 8657 & $\begin{array}{l}0.240 * * * \\
(0.070)\end{array}$ & 8794 & $\begin{array}{l}1.354 * * * \\
(0.132)\end{array}$ & 8196 & $\begin{array}{l}0.191 * * * \\
(0.073)\end{array}$ & 8816 \\
\hline $\begin{array}{l}\text { Test of OIR } \\
\text { Chi-stat } \\
\text { (p-value) }\end{array}$ & $\begin{array}{l}1.79 \\
(0.40)\end{array}$ & & $\begin{array}{l}1.05 \\
(0.60)\end{array}$ & & $\begin{array}{l}2.95 \\
(0.22)\end{array}$ & & $\begin{array}{l}3.17 \\
(0.20)\end{array}$ & & $\begin{array}{l}0.58 \\
(0.74)\end{array}$ & \\
\hline
\end{tabular}

* Robust standard errors in parentheses, * significant at 10\%; ** significant at 5\%; *** significant at $1 \%$. Specification (1) includes log of PC income as an instrument; (2) includes dwelling characteristics as instruments; and (3) includes both income and dwelling characteristics as instruments. Other variables included in all three specifications are household size and composition, husband's and wife's education, whether the head of household is an agricultural worker, local prices of food items and availability of electricity, sewage and health facilities at the village level.

Table 7: First stage regression for P.C. value of consumption in the unitary model.

\begin{tabular}{lccc}
\hline \hline & $\begin{array}{c}\text { P.C. value of } \\
\text { consumption } \\
(1)\end{array}$ & $\begin{array}{c}\text { P.C. value of } \\
\text { consumption } \\
(2)\end{array}$ & $\begin{array}{c}\text { P.C. value of } \\
\text { consumption } \\
(3)\end{array}$ \\
\hline Log of P.C. income & $0.082^{* * *}$ & & $\begin{array}{c}0.078^{* * *} \\
(0.009)\end{array}$ \\
Piped water & $(0.009)$ & $0.042^{* * *}$ & $\begin{array}{c}0.042^{* * *} \\
(0.011)\end{array}$ \\
Cement floor & & $(0.011)$ & $0.138^{* * *}$ \\
& & $0.140^{* * *}$ & $(0.011)$ \\
Sample size & & $(0.011)$ & 8947 \\
R-squared & 8947 & 9028 & 0.26 \\
F-test: IVs jointly significant & 0.25 & 0.26 & 89.21 \\
\hline
\end{tabular}

Robust standard errors in parentheses, $* * *$ indicates significance at $1 \%$ level. Specification (1) includes log of PC income as an instrument; (2) includes dwelling characteristics as instruments; and (3) includes both income and dwelling characteristics as instruments. In all three specifications, the other variables are household size and composition, husband's and wife's education, whether the head of household is an agricultural worker, local prices of food items and availability of electricity, sewage and health facilities at the village level. 
Table 8: Testing the exogeneity of the treatment dummy in the unitary model.

\begin{tabular}{lc}
\hline \hline & c-stat \\
Per mouth calorie consumption & 13.11 \\
& $(0.0003)$ \\
Per mouth calorie consumption from vegetables and fruits & 8.46 \\
& $(0.0036)$ \\
Per mouth calorie consumption from grains and cereals & 14.29 \\
& $(0.0001)$ \\
Per mouth calorie consumption from meat and meat products & 0.09 \\
& $(0.75)$ \\
Per mouth calorie consumption from other food & 9.62 \\
& $(0.0019)$ \\
\hline
\end{tabular}

Table 9: 2SLS estimation of the restricted collective model for calorie demand.

\begin{tabular}{lccccc}
\hline \hline & Total & $\begin{array}{c}\text { Vegetables } \\
\text { and Fruits }\end{array}$ & $\begin{array}{c}\text { Grains and } \\
\text { Cereals }\end{array}$ & $\begin{array}{c}\text { Meat and } \\
\text { meat } \\
\text { products }\end{array}$ & Other food \\
\hline Log P.C. value of consumption & $\begin{array}{c}0.278^{* * *} \\
(0.050)\end{array}$ & $\begin{array}{c}1.428^{* * *} \\
(0.123)\end{array}$ & $\begin{array}{c}0.214^{* * *} \\
(0.073)\end{array}$ & $\begin{array}{c}1.364^{* * *} \\
(0.135)\end{array}$ & $\begin{array}{c}0.174^{* *} \\
(0.075)\end{array}$ \\
Log of wife's non labor income & $\begin{array}{c}0.007^{* * *} \\
(0.002)\end{array}$ & $\begin{array}{c}0.013^{* * *} \\
(0.005)\end{array}$ & $\begin{array}{c}0.011^{* * *} \\
(0.003)\end{array}$ & $\begin{array}{c}-0.002 \\
(0.005)\end{array}$ & $\begin{array}{c}0.009^{* * *} \\
(0.003)\end{array}$ \\
& 8163 & 8657 & 8794 & 8196 & 8816 \\
Sample size & 1.02 & 1.04 & 1.91 & 3.05 & 1.01 \\
test of OIR for all IVs: & $(0.59)$ & $(0.49)$ & $(0.38)$ & $(0.21)$ & $(0.60)$ \\
chi2-stat and p-value & 1.02 & 0.58 & 1.82 & 2.99 & 0.85 \\
test of OIR for treatment group & $(0.31)$ & $(0.44)$ & $(0.17)$ & $(0.08)$ & $(0.35)$ \\
indicator: chi2-stat (p-value) & & & & & \\
\hline
\end{tabular}

Robust standard errors in parentheses, $* *$ significance at $5 \%$ level, $* * *$ significance at $1 \%$ level.

Other explanatory variables included in the estimation are household size and composition, husband's and wife's education, whether the head of household is an agricultural worker, local prices of food items and availability of electricity, sewage and health facilities at the village level.

Instrumental variables include log of P.C. income, a binary variable indicating assignment to treatment group, as well as dwelling characteristics. 
Table 10: 2SLS estimation of the unrestricted collective model for calorie demand.

\begin{tabular}{lccccc}
\hline \hline & Total & $\begin{array}{c}\text { Vegetables } \\
\text { and Fruits }\end{array}$ & $\begin{array}{c}\text { Grains and } \\
\text { Cereals }\end{array}$ & $\begin{array}{c}\text { Meat and } \\
\text { meat } \\
\text { products }\end{array}$ & Other food \\
\hline Log P.C. value of consumption & $\begin{array}{c}0.476^{* * *} \\
(0.087)\end{array}$ & $\begin{array}{c}1.010^{* * *} \\
(0.208)\end{array}$ & $\begin{array}{c}0.462^{* * *} \\
(0.115)\end{array}$ & $\begin{array}{c}1.530^{* * *} \\
(0.226)\end{array}$ & $\begin{array}{c}-0.021 \\
(0.135)\end{array}$ \\
Log of husband's labor income & -0.004 & 0.016 & -0.005 & $-0.028^{* *}$ & 0.006 \\
& $(0.005)$ & $(0.013)$ & $(0.007)$ & $(0.014)$ & $(0.008)$ \\
Log of wife's non labor income & $0.005^{* *}$ & $0.016^{* * *}$ & $0.005^{*}$ & -0.001 & $0.012^{* * *}$ \\
& $(0.002)$ & $(0.005)$ & $(0.003)$ & $(0.006)$ & $(0.004)$ \\
& & & & & \\
Sample size & 6311 & 6311 & 6311 & 6311 & 6311 \\
Test of OIR for all IVs: & 9.52 & 8.82 & 6.57 & 10.25 & 10.82 \\
chi2-stat and p-value & $(0.21)$ & $(.26)$ & $(.47)$ & $(.17)$ & $(.14)$ \\
& & & & & \\
Test of OIR for treatment group & .37 & 1.29 & .27 & 4.02 & 2.67 \\
indicator: chi2-stat (p-value) & $(.53)$ & $(.25)$ & $(.60)$ & $(.04)$ & $(.10)$ \\
\hline
\end{tabular}

Robust standard errors in parentheses, * $10 \%, * * 5 \%$ and $* * * 1 \%$ significance levels. Other explanatory variables included in the estimation are household size and composition, husband's and wife's education, whether the head of household is an agricultural worker, local prices of food items and availability of electricity, sewage and health facilities at the village level. Instrumental variables include log of P.C. income, treatment group indicator, household dwellings as well as characteristics at the time of marriage.

Table 11: First stage regressions in the case of the restricted collective model.

\begin{tabular}{lcc}
\hline \hline & Log of P.C. value of consumption & Log of wife's non-labor income \\
\hline Treatment group indicator & $0.049^{* * *}$ & $4.507^{* * *}$ \\
& $(0.010)$ & $(0.021)$ \\
Log of P.C. income & $0.075^{* * *}$ & 0.028 \\
& $(0.009)$ & $(0.024)$ \\
Piped water & $0.038^{* * *}$ & $0.081^{* * *}$ \\
& $(0.011)$ & $(0.023)$ \\
Cement floor & $0.137^{* * *}$ & $0.041^{*}$ \\
& $(0.011)$ & $(0.023)$ \\
Sample size & 8947 & 9136 \\
R-squared & 0.27 & 0.85 \\
F-test: IVs jointly significant & 72.76 & 12225 \\
\hline
\end{tabular}

Robust standard errors in parentheses, * $10 \%, * * 5 \%$ and $* * * 1 \%$ significance levels. Other explanatory variables included in the estimation are household size and composition, husband's and wife's education, whether the head of household is an agricultural worker, local prices of food items and availability of electricity, sewage and health facilities at the village level. 
Table 12: Testing the exogeneity of the treatment dummy in the unrestricted collective model: without young children, and with young children.

\begin{tabular}{lcc}
\hline \hline C-stat (p-value) & without young children & with young children \\
\hline Per mouth calorie consumption & 0.01 & 0.10 \\
& $(0.90)$ & $(0.74)$ \\
Per mouth calorie consumption from vegetables and fruits & 2.13 & 0.16 \\
& $(0.14)$ & $(0.68)$ \\
Per mouth calorie consumption from grains and cereals & 0.007 & 0.30 \\
& $(0.93)$ & $(0.58)$ \\
Per mouth calorie consumption from meat and meat products & 1.55 & 1.61 \\
& $(0.21)$ & $(0.20)$ \\
Per mouth calorie consumption from other food & 0.04 & 1.98 \\
& $(0.82)$ & $(0.15)$ \\
\hline
\end{tabular}

Table 13: First stage regressions in the case of the unrestricted collective model.

\begin{tabular}{|c|c|c|c|}
\hline & $\begin{array}{l}\text { Log of P.C. Value of } \\
\text { consumption }\end{array}$ & $\begin{array}{l}\text { Log of Husband's } \\
\text { labor income }\end{array}$ & $\begin{array}{l}\text { Log of Wife's non- } \\
\text { labor income }\end{array}$ \\
\hline Treatment group indicator & $\begin{array}{c}0.051 * * * \\
(0.011)\end{array}$ & $\begin{array}{c}-0.324 * * * \\
(0.040)\end{array}$ & $\begin{array}{c}4.549^{* * *} \\
(0.022)\end{array}$ \\
\hline Log of P.C. income & $\begin{array}{c}0.072 * * * \\
(0.010)\end{array}$ & $\begin{array}{l}1.824 * * * \\
(0.045)\end{array}$ & $\begin{array}{c}0.013 \\
(0.025)\end{array}$ \\
\hline Piped water & $\begin{array}{l}0.046^{* * *} \\
(0.012)\end{array}$ & $\begin{array}{c}0.035 \\
(0.046)\end{array}$ & $\begin{array}{l}0.080 * * * \\
(0.024)\end{array}$ \\
\hline $\begin{array}{l}\text { Wife stays in the same village after } \\
\text { marriage }\end{array}$ & $\begin{array}{c}-0.029 * * * \\
(0.010)\end{array}$ & $\begin{array}{c}0.060 \\
(0.038)\end{array}$ & $\begin{array}{c}0.015 \\
(0.020)\end{array}$ \\
\hline Husband's father had shoes & $\begin{array}{l}0.023 \\
(0.016)\end{array}$ & $\begin{array}{l}-0.032 \\
(0.057)\end{array}$ & $\begin{array}{l}-0.018 \\
(0.028)\end{array}$ \\
\hline $\begin{array}{l}\text { Husband's father had some primary } \\
\text { school education }\end{array}$ & $\begin{array}{l}-0.002 \\
(0.012)\end{array}$ & $\begin{array}{l}-0.061 \\
(0.047)\end{array}$ & $\begin{array}{l}-0.046^{*} \\
(0.025)\end{array}$ \\
\hline $\begin{array}{l}\text { Husband's mother had some } \\
\text { primary school education }\end{array}$ & $\begin{array}{c}0.012 \\
(0.014)\end{array}$ & $\begin{array}{c}0.028 \\
(0.051)\end{array}$ & $\begin{array}{c}0.012 \\
(0.026)\end{array}$ \\
\hline Wife's father had shoes & $\begin{array}{l}0.050 * * * \\
(0.016)\end{array}$ & $\begin{array}{l}-0.076 \\
(0.057)\end{array}$ & $\begin{array}{l}0.066^{* *} \\
(0.029)\end{array}$ \\
\hline $\begin{array}{l}\text { Wife's father had some primary } \\
\text { education }\end{array}$ & $\begin{array}{c}0.031 * * * \\
(0.011)\end{array}$ & $\begin{array}{l}0.075^{*} \\
(0.042)\end{array}$ & $\begin{array}{c}0.002 \\
(0.021)\end{array}$ \\
\hline Husband owned house & $\begin{array}{c}0.033 * * \\
(0.013)\end{array}$ & $\begin{array}{c}-0.062 \\
(0.048)\end{array}$ & $\begin{array}{l}-0.042 \\
(0.026)\end{array}$ \\
\hline Sample size & 7814 & 7911 & 7981 \\
\hline R-squared & 0.26 & 0.41 & 0.87 \\
\hline F-test: IVs jointly significant & 19.40 & 169 & 4616 \\
\hline
\end{tabular}

Robust standard errors in parentheses, * significant at 10\%; ** significant at 5\%; *** significant at $1 \%$. Other explanatory variables included in the estimation are household size and composition, husband's and wife's education, whether the head of household is an agricultural worker, local prices of food items and availability of electricity, sewage and health facilities at the village level. 
Table 14: Testing for the strict exogeneity restriction for the extended family.

\begin{tabular}{|c|c|c|}
\hline & $\begin{array}{c}\text { Change in per mouth calorie } \\
\text { consumption }\end{array}$ & $\begin{array}{c}\text { Change in per mouth calorie } \\
\text { consumption }\end{array}$ \\
\hline Change in log of P.C. value of consumption & $\begin{array}{c}0.454^{* * *} \\
(0.006)\end{array}$ & $\begin{array}{c}0.455^{* * *} \\
(0.007)\end{array}$ \\
\hline Change in number of income earners & $\begin{array}{l}-0.015^{* * * *} \\
(0.004)\end{array}$ & \\
\hline Change in household size & $\begin{array}{c}0.006 \\
(0.011)\end{array}$ & $\begin{array}{c}0.006 \\
(0.011)\end{array}$ \\
\hline Log of P.C. value of consumption & $\begin{array}{l}-0.002 \\
(0.006)\end{array}$ & $\begin{array}{l}-0.006 \\
(0.006)\end{array}$ \\
\hline Number of income earners & $\begin{array}{c}-0.013 * * * \\
(0.004)\end{array}$ & \\
\hline Change in number of children below age 4 & $\begin{array}{c}0.055^{* * *} \\
(0.009)\end{array}$ & $\begin{array}{c}0.053 * * * \\
(0.009)\end{array}$ \\
\hline Change in number of 5-10 years old children & $\begin{array}{c}0.045^{* * *} \\
(0.009)\end{array}$ & $\begin{array}{c}0.044 * * * \\
(0.009)\end{array}$ \\
\hline Change in number of $11-14$ years old boys & $\begin{array}{c}0.040 * * * \\
(0.011)\end{array}$ & $\begin{array}{c}0.039 * * * \\
(0.011)\end{array}$ \\
\hline Change in number of $11-14$ years old girls & $\begin{array}{c}0.055 * * * \\
(0.011)\end{array}$ & $\begin{array}{c}0.054 * * * \\
(0.011)\end{array}$ \\
\hline Change in number of $15-19$ years old boys & $\begin{array}{c}0.047 * * * \\
(0.011)\end{array}$ & $\begin{array}{c}0.046 * * * \\
(0.011)\end{array}$ \\
\hline Change in number of $15-19$ years old girls & $\begin{array}{c}0.042 * * * \\
(0.010)\end{array}$ & $\begin{array}{c}0.041 * * * \\
(0.010)\end{array}$ \\
\hline Change in number of 20-34 years old men & $\begin{array}{l}0.019^{*} \\
(0.010)\end{array}$ & $\begin{array}{l}0.021 * * \\
(0.010)\end{array}$ \\
\hline Change in number of $20-34$ years old women & $\begin{array}{c}0.011 \\
(0.011)\end{array}$ & $\begin{array}{c}0.009 \\
(0.011)\end{array}$ \\
\hline Change in number of $35-54$ years old men & $\begin{array}{c}0.045 * * * \\
(0.016)\end{array}$ & $\begin{array}{c}0.049 * * * \\
(0.016)\end{array}$ \\
\hline Change in number of $35-54$ years old women & $\begin{array}{c}0.014 \\
(0.017)\end{array}$ & $\begin{array}{l}0.013 \\
(0.017)\end{array}$ \\
\hline Change in number of men above age 55 & $\begin{array}{c}0.015 \\
(0.021)\end{array}$ & $\begin{array}{c}0.020 \\
(0.021)\end{array}$ \\
\hline Change in number of women above age 55 & $\begin{array}{l}0.017 \\
(0.020)\end{array}$ & $\begin{array}{c}0.015 \\
(0.020)\end{array}$ \\
\hline Number of new female income earners & & $\begin{array}{c}0.033 * * * \\
(0.010)\end{array}$ \\
\hline Number of women who stopped earning income & & $\begin{array}{c}0.034 * * * \\
(0.011)\end{array}$ \\
\hline Number of men who stopped earning income & & $\begin{array}{c}0.013 \\
(0.008)\end{array}$ \\
\hline Number of new male income earners & & $\begin{array}{c}-0.018^{* *} \\
(0.008)\end{array}$ \\
\hline Number of male income earners & & $\begin{array}{l}-0.023 * * * \\
(0.005)\end{array}$ \\
\hline Number of female income earners & & $\begin{array}{l}-0.011^{*} \\
(0.006)\end{array}$ \\
\hline Constant & $\begin{array}{c}0.024 \\
(0.034)\end{array}$ & $\begin{array}{c}0.047 \\
(0.035)\end{array}$ \\
\hline $\begin{array}{l}\text { Sample size } \\
\text { R-squared }\end{array}$ & $\begin{array}{c}35489 \\
0.18\end{array}$ & $\begin{array}{c}35489 \\
0.18\end{array}$ \\
\hline
\end{tabular}

Robust standard errors in parentheses, * significant at $10 \%$; ** significant at $5 \%$; *** significant at $1 \%$. 
Table 15: First stage regression for the estimation of the first-difference model.

\begin{tabular}{|c|c|c|c|c|c|}
\hline & $\begin{array}{l}\text { Change in } \\
\text { number of } \\
\text { income } \\
\text { earners }\end{array}$ & $\begin{array}{c}\text { Number of } \\
\text { new male } \\
\text { earners }\end{array}$ & $\begin{array}{l}\text { Number of } \\
\text { new female } \\
\text { earners }\end{array}$ & $\begin{array}{c}\text { Number of } \\
\text { men who } \\
\text { stopped } \\
\text { earning } \\
\text { income }\end{array}$ & $\begin{array}{c}\text { Number of } \\
\text { men who } \\
\text { stopped } \\
\text { earning } \\
\text { income }\end{array}$ \\
\hline Log of P.C. income & $\begin{array}{c}0.355^{* * *} \\
(0.006)\end{array}$ & $\begin{array}{c}0.111 * * * \\
(0.003)\end{array}$ & $\begin{array}{c}0.020^{* * * *} \\
(0.003)\end{array}$ & $\begin{array}{l}-0.155^{* * *} \\
(0.003)\end{array}$ & $\begin{array}{c}-0.008 * * * \\
(0.002)\end{array}$ \\
\hline Number of $15-19$ years old boys & $\begin{array}{l}0.018^{* *} \\
(0.009)\end{array}$ & $\begin{array}{c}0.096 * * * \\
(0.004)\end{array}$ & $\begin{array}{l}-0.002 \\
(0.003)\end{array}$ & $\begin{array}{c}0.080^{* * *} \\
(0.003)\end{array}$ & $\begin{array}{c}0.017 * * * \\
(0.002)\end{array}$ \\
\hline Number of 15-19 years old girls & $\begin{array}{l}0.014^{*} \\
(0.009)\end{array}$ & $\begin{array}{c}0.020 * * * \\
(0.004)\end{array}$ & $\begin{array}{c}0.045 * * * \\
(0.004)\end{array}$ & $\begin{array}{l}0.006^{*} \\
(0.003)\end{array}$ & $\begin{array}{c}0.045^{* * * *} \\
(0.003)\end{array}$ \\
\hline Treatment dummy & & $\begin{array}{c}-0.027 * * * \\
(0.005)\end{array}$ & $\begin{array}{c}0.058 * * * \\
(0.004)\end{array}$ & $\begin{array}{c}0.047 * * * \\
(0.004)\end{array}$ & $\begin{array}{l}-0.040 * * * \\
(0.003)\end{array}$ \\
\hline Number of 20-34 years old men & & $\begin{array}{c}0.041 * * * \\
(0.004)\end{array}$ & $\begin{array}{c}-0.020 * * * \\
(0.003)\end{array}$ & $\begin{array}{c}0.049 * * * \\
(0.003)\end{array}$ & $\begin{array}{c}-0.006^{* *} \\
(0.002)\end{array}$ \\
\hline Number of 20-34 years old women & & $\begin{array}{c}0.015^{* * *} \\
(0.004)\end{array}$ & $\begin{array}{c}0.026^{* * *} \\
(0.004)\end{array}$ & $\begin{array}{c}-0.031 * * * \\
(0.003)\end{array}$ & $\begin{array}{c}0.028 * * * \\
(0.003)\end{array}$ \\
\hline Change in household size & $\begin{array}{c}0.034 * * \\
(0.016)\end{array}$ & $\begin{array}{l}-0.007 \\
(0.009)\end{array}$ & $\begin{array}{l}0.013^{*} \\
(0.007)\end{array}$ & $\begin{array}{c}-0.019 * * * \\
(0.006)\end{array}$ & $\begin{array}{l}-0.003 \\
(0.005)\end{array}$ \\
\hline $\begin{array}{l}\text { Change in number of children } \\
\text { below age } 4\end{array}$ & $\begin{array}{l}-0.017 \\
(0.013)\end{array}$ & $\begin{array}{c}-0.015^{* *} \\
(0.007)\end{array}$ & $\begin{array}{c}0.024 * * * \\
(0.005)\end{array}$ & $\begin{array}{c}0.011^{* *} \\
(0.005)\end{array}$ & $\begin{array}{l}0.008^{*} \\
(0.005)\end{array}$ \\
\hline $\begin{array}{l}\text { Change in number of } 5-10 \text { years } \\
\text { old children }\end{array}$ & $\begin{array}{c}-0.036^{* * *} \\
(0.013)\end{array}$ & $\begin{array}{l}-0.019 * * * \\
(0.007)\end{array}$ & $\begin{array}{l}-0.002 \\
(0.005)\end{array}$ & $\begin{array}{l}-0.001 \\
(0.005)\end{array}$ & $\begin{array}{c}0.004 \\
(0.004)\end{array}$ \\
\hline $\begin{array}{l}\text { Change in number of } 11-14 \text { years } \\
\text { old boys }\end{array}$ & $\begin{array}{l}-0.027 \\
(0.018)\end{array}$ & $\begin{array}{l}-0.001 \\
(0.009)\end{array}$ & $\begin{array}{l}-0.011^{*} \\
(0.007)\end{array}$ & $\begin{array}{c}0.009 \\
(0.007)\end{array}$ & $\begin{array}{l}-0.001 \\
(0.005)\end{array}$ \\
\hline $\begin{array}{l}\text { Change in number of } 11-14 \text { years } \\
\text { old girls }\end{array}$ & $\begin{array}{c}-0.047 * * * \\
(0.017)\end{array}$ & $\begin{array}{l}-0.011 \\
(0.009)\end{array}$ & $\begin{array}{l}-0.002 \\
(0.007)\end{array}$ & $\begin{array}{c}0.005 \\
(0.006)\end{array}$ & $\begin{array}{c}0.022 * * * \\
(0.006)\end{array}$ \\
\hline $\begin{array}{l}\text { Change in number of } 15-19 \text { years } \\
\text { old boys }\end{array}$ & $\begin{array}{l}-0.002 \\
(0.018)\end{array}$ & $\begin{array}{c}-0.027 * * * \\
(0.009)\end{array}$ & $\begin{array}{c}0.005 \\
(0.006)\end{array}$ & $\begin{array}{c}-0.013 * * \\
(0.006)\end{array}$ & $\begin{array}{l}-0.006 \\
(0.005)\end{array}$ \\
\hline $\begin{array}{l}\text { Change in number of } 15-19 \text { years } \\
\text { old girls }\end{array}$ & $\begin{array}{c}-0.031^{* *} \\
(0.016)\end{array}$ & $\begin{array}{l}-0.011 \\
(0.008)\end{array}$ & $\begin{array}{l}-0.003 \\
(0.006)\end{array}$ & $\begin{array}{c}0.009 \\
(0.006)\end{array}$ & $\begin{array}{l}-0.003 \\
(0.005)\end{array}$ \\
\hline $\begin{array}{l}\text { Change in number of } 20-34 \text { years } \\
\text { old men }\end{array}$ & $\begin{array}{l}-0.015 \\
(0.016)\end{array}$ & $\begin{array}{l}-0.005 \\
(0.009)\end{array}$ & $\begin{array}{l}0.008 \\
(0.006)\end{array}$ & $\begin{array}{c}0.014 * * \\
(0.006)\end{array}$ & $\begin{array}{l}0.006 \\
(0.005)\end{array}$ \\
\hline $\begin{array}{l}\text { Change in number of } 20-34 \text { years } \\
\text { old women }\end{array}$ & $\begin{array}{l}-0.007 \\
(0.018)\end{array}$ & $\begin{array}{l}-0.014 \\
(0.009)\end{array}$ & $\begin{array}{c}0.007 \\
(0.007)\end{array}$ & $\begin{array}{l}0.011^{*} \\
(0.006)\end{array}$ & $\begin{array}{c}0.001 \\
(0.005)\end{array}$ \\
\hline $\begin{array}{l}\text { Change in number of } 35-54 \text { years } \\
\text { old men }\end{array}$ & $\begin{array}{c}-0.054 * * \\
(0.023)\end{array}$ & $\begin{array}{c}0.011 \\
(0.013)\end{array}$ & $\begin{array}{c}-0.033 * * * \\
(0.009)\end{array}$ & $\begin{array}{c}0.043 * * * \\
(0.008)\end{array}$ & $\begin{array}{l}-0.011 \\
(0.007)\end{array}$ \\
\hline $\begin{array}{l}\text { Change in number of } 35-54 \text { years } \\
\text { old women }\end{array}$ & $\begin{array}{c}0.004 \\
(0.025)\end{array}$ & $\begin{array}{c}0.003 \\
(0.014)\end{array}$ & $\begin{array}{c}0.007 \\
(0.010)\end{array}$ & $\begin{array}{l}-0.012 \\
(0.009)\end{array}$ & $\begin{array}{c}0.007 \\
(0.007)\end{array}$ \\
\hline $\begin{array}{l}\text { Change in number of men above } \\
\text { age } 55\end{array}$ & $\begin{array}{c}-0.078 * * * \\
(0.029)\end{array}$ & $\begin{array}{c}0.023 \\
(0.015)\end{array}$ & $\begin{array}{c}-0.050 * * * \\
(0.012)\end{array}$ & $\begin{array}{c}0.051^{* * *} \\
(0.010)\end{array}$ & $\begin{array}{c}0.002 \\
(0.009)\end{array}$ \\
\hline $\begin{array}{l}\text { Change in number of women } \\
\text { above age } 55\end{array}$ & $\begin{array}{l}-0.008 \\
(0.029)\end{array}$ & $\begin{array}{l}-0.024 \\
(0.015)\end{array}$ & $\begin{array}{l}0.021^{*} \\
(0.011)\end{array}$ & $\begin{array}{c}0.011 \\
(0.010)\end{array}$ & $\begin{array}{c}0.003 \\
(0.008)\end{array}$ \\
\hline Constant & $\begin{array}{c}-1.687 * * * \\
(0.032)\end{array}$ & $\begin{array}{l}-0.409 * * * \\
(0.015)\end{array}$ & $\begin{array}{l}-0.017 \\
(0.016)\end{array}$ & $\begin{array}{l}0.885 * * * \\
(0.016)\end{array}$ & $\begin{array}{c}0.103 * * * \\
(0.010)\end{array}$ \\
\hline Sample size & 34556 & 34556 & 34556 & 34556 & 34556 \\
\hline R-squared & 0.10 & 0.07 & 0.02 & 0.14 & 0.02 \\
\hline F-test: IVs jointly significant & 1209.21 & 437.23 & 80.82 & 605.15 & 128.04 \\
\hline
\end{tabular}

Robust standard errors in parentheses, * significant at 10\%; ** significant at 5\%; *** significant at 1\%. 
Table 16: Estimation of the first-difference model in the case of the extended family.

\begin{tabular}{|c|c|c|}
\hline & $\begin{array}{c}\text { Change in per mouth calorie } \\
\text { consumption } \\
(1)\end{array}$ & $\begin{array}{c}\text { Change in per mouth calorie } \\
\text { consumption } \\
(2)\end{array}$ \\
\hline Change in number of income earners & $\begin{array}{c}-0.091 * * * \\
(0.011)\end{array}$ & \\
\hline Number of new female income earners & & $\begin{array}{c}0.198^{* *} \\
(0.080)\end{array}$ \\
\hline $\begin{array}{l}\text { Number of women who stopped } \\
\text { earning income }\end{array}$ & & $\begin{array}{l}-0.154^{*} \\
(0.092)\end{array}$ \\
\hline Number of new male income earners & & $\begin{array}{c}-0.102 * * * \\
(0.035)\end{array}$ \\
\hline $\begin{array}{l}\text { Number of men who stopped earning } \\
\text { income }\end{array}$ & & $\begin{array}{c}0.178 * * * \\
(0.030)\end{array}$ \\
\hline $\begin{array}{l}\text { Change in log of P.C. value of } \\
\text { consumption }\end{array}$ & $\begin{array}{l}0.466 * * * \\
(0.006)\end{array}$ & $\begin{array}{c}0.460 * * * \\
(0.006)\end{array}$ \\
\hline Change in household size & $\begin{array}{c}0.003 \\
(0.011)\end{array}$ & $\begin{array}{l}-0.001 \\
(0.012)\end{array}$ \\
\hline $\begin{array}{l}\text { Change in number of children below } \\
\text { age } 4\end{array}$ & $\begin{array}{l}0.060 * * * \\
(0.010)\end{array}$ & $\begin{array}{l}0.052 * * * \\
(0.010)\end{array}$ \\
\hline $\begin{array}{l}\text { Change in number of } 5-10 \text { years old } \\
\text { children }\end{array}$ & $\begin{array}{c}0.046 * * * \\
(0.010)\end{array}$ & $\begin{array}{c}0.049 * * * \\
(0.010)\end{array}$ \\
\hline $\begin{array}{l}\text { Change in number of } 11-14 \text { years old } \\
\text { boys }\end{array}$ & $\begin{array}{c}0.035 * * * \\
(0.012)\end{array}$ & $\begin{array}{l}0.039 * * * \\
(0.012)\end{array}$ \\
\hline $\begin{array}{l}\text { Change in number of } 11-14 \text { years old } \\
\text { girls }\end{array}$ & $\begin{array}{c}0.048 * * * \\
(0.011)\end{array}$ & $\begin{array}{c}0.055^{* * *} \\
(0.012)\end{array}$ \\
\hline $\begin{array}{l}\text { Change in number of } 15-19 \text { years old } \\
\text { boys }\end{array}$ & $\begin{array}{l}0.051 * * * \\
(0.011)\end{array}$ & $\begin{array}{c}0.047 * * * \\
(0.011)\end{array}$ \\
\hline $\begin{array}{l}\text { Change in number of } 15-19 \text { years old } \\
\text { girls }\end{array}$ & $\begin{array}{c}0.041 * * * \\
(0.010)\end{array}$ & $\begin{array}{c}0.039 * * * \\
(0.011)\end{array}$ \\
\hline $\begin{array}{l}\text { Change in number of } 20-34 \text { years old } \\
\text { men }\end{array}$ & $\begin{array}{l}0.021^{*} \\
(0.011)\end{array}$ & $\begin{array}{c}0.017 \\
(0.011)\end{array}$ \\
\hline $\begin{array}{l}\text { Change in number of } 20-34 \text { years old } \\
\text { women }\end{array}$ & $\begin{array}{c}0.005 \\
(0.012)\end{array}$ & $\begin{array}{c}0.002 \\
(0.012)\end{array}$ \\
\hline $\begin{array}{l}\text { Change in number of } 35-54 \text { years old } \\
\text { men }\end{array}$ & $\begin{array}{l}0.046 * * * \\
(0.016)\end{array}$ & $\begin{array}{c}0.049 * * * \\
(0.017)\end{array}$ \\
\hline $\begin{array}{l}\text { Change in number of } 35-54 \text { years old } \\
\text { women }\end{array}$ & $\begin{array}{c}0.001 \\
(0.018)\end{array}$ & $\begin{array}{c}0.001 \\
(0.018)\end{array}$ \\
\hline Change in number of men above age & 0.014 & 0.025 \\
\hline 55 & $(0.021)$ & $(0.022)$ \\
\hline $\begin{array}{l}\text { Change in number of women above } \\
\text { age } 55\end{array}$ & $\begin{array}{l}-0.004 \\
(0.021)\end{array}$ & $\begin{array}{l}-0.013 \\
(0.021)\end{array}$ \\
\hline Constant & $\begin{array}{c}0.004 \\
(0.004)\end{array}$ & $\begin{array}{c}-0.032^{* *} \\
(0.015)\end{array}$ \\
\hline Sample size & 32065 & 32065 \\
\hline
\end{tabular}

Robust standard errors in parentheses, * significant at 10\%; ** significant at 5\%; *** significant at $1 \%$. In specification (1), instruments are log of P.C. income, number of 15-19 years old boys and girls; in specification (2), instruments are log of P.C. income, number of 15-19 years old boys and girls, number of 20-34 years old men and women and the treatment dummy. 
Table 16: continued.

\begin{tabular}{lcc}
\hline \hline & $(1)$ & $(2)$ \\
\hline $\begin{array}{l}\text { Effect of women who stopped earning } \\
\text { income = - Effect of number of new } \\
\text { female income earners }\end{array}$ & 0.14 \\
$\begin{array}{l}\text { Effect of men who stopped earning } \\
\text { income = - Effect of number of new }\end{array}$ & $(0.71)$ \\
male income earners & & 1.85 \\
$\begin{array}{l}\text { Effect of women who stopped earning } \\
\text { income = Effect of men who stopped }\end{array}$ & & $(0.17)$ \\
earning income & & 9.78 \\
Effect of number of new female & & $(0.02)$ \\
income earners = Effect of number of & & 11 \\
new male income earners & & $(0.0009)$ \\
Test of OIR for all IVs & 1.27 & 0.47 \\
Test of OIR for log of P.C. income & $(0.52)$ & $(0.78)$ \\
& 0.86 & \\
test of OIR for treatment dummy & $(0.35)$ & 0.22 \\
& & $(0.63)$ \\
\hline
\end{tabular}

In specification (1), instruments are log of P.C. income, number of 15-19 years old boys and girls; in specification (2), instruments are log of P.C. income, number of 15-19 years old boys and girls, number of 20-34 years old men and women and the treatment dummy.

Table 17: Testing the unitary model restriction based on the restricted collective model and the unrestricted collective model.

\begin{tabular}{lcc}
\hline \hline & $\begin{array}{c}\text { Restricted collective model } \\
\text { chi2 }(1) \\
(\mathrm{p} \text {-value })\end{array}$ & $\begin{array}{c}\text { Unrestricted collective model } \\
\text { chi2 }(2) \\
(\mathrm{p} \text {-value })\end{array}$ \\
\hline Total calories & 13.59 & 6.66 \\
& $(0.0002)$ & $(0.03)$ \\
Vegetable and fruits calories & 8.39 & 8.70 \\
& $(0.0038)$ & $(0.01)$ \\
Cereals and grains calories & 14.78 & 4.55 \\
& $(0.0001)$ & $(0.10)$ \\
Meat and meat products calories & 0.17 & 4.44 \\
& $(0.6814)$ & $(0.11)$ \\
Other food calories & 8.84 & 12.60 \\
& $(0.0029)$ & $(0.0002)$ \\
\hline
\end{tabular}

Table 18: Testing Pareto-efficiency in the unrestricted collective model for pairs of goods.

\begin{tabular}{lccc}
\hline $\begin{array}{c}\text { chi2 }(1) \\
\text { (p-value) }\end{array}$ & $\begin{array}{c}\text { Vegetable and } \\
\text { fruits calories }\end{array}$ & $\begin{array}{l}\text { Cereals and grains } \\
\text { calories }\end{array}$ & $\begin{array}{l}\text { Meat and meat } \\
\text { products calories }\end{array}$ \\
\hline Cereals and grains calories & 4.20 & - & - \\
Meat and meat products calories & $(0.04)$ & 1.39 & - \\
Other food calories & 1.40 & $(0.23)$ & 1.99 \\
& $(0.23)$ & 2.62 & $(0.15)$ \\
\hline
\end{tabular}

